\title{
Corporate responsibility, beyond voluntarism : regulatory options to reinforce the licence to operate
}

Citation for published version (APA):

Eijsbouts, J. (2011). Corporate responsibility, beyond voluntarism : regulatory options to reinforce the licence to operate. Maastricht University Press. https://doi.org/10.26481/spe.20111020je

Document status and date:

Published: 20/10/2011

DOI:

10.26481/spe.20111020je

Document Version:

Publisher's PDF, also known as Version of record

\section{Please check the document version of this publication:}

- A submitted manuscript is the version of the article upon submission and before peer-review. There can be important differences between the submitted version and the official published version of record.

People interested in the research are advised to contact the author for the final version of the publication, or visit the DOI to the publisher's website.

- The final author version and the galley proof are versions of the publication after peer review.

- The final published version features the final layout of the paper including the volume, issue and page numbers.

Link to publication

\footnotetext{
General rights rights.

- You may freely distribute the URL identifying the publication in the public portal. please follow below link for the End User Agreement:

www.umlib.nl/taverne-license

Take down policy

If you believe that this document breaches copyright please contact us at:

repository@maastrichtuniversity.nl

providing details and we will investigate your claim.
}

Copyright and moral rights for the publications made accessible in the public portal are retained by the authors and/or other copyright owners and it is a condition of accessing publications that users recognise and abide by the legal requirements associated with these

- Users may download and print one copy of any publication from the public portal for the purpose of private study or research.

- You may not further distribute the material or use it for any profit-making activity or commercial gain

If the publication is distributed under the terms of Article $25 \mathrm{fa}$ of the Dutch Copyright Act, indicated by the "Taverne" license above, 
Corporate responsibility, beyond voluntarism Regulatory options to reinforce the licence to operate 


\section{Colofon}

Print and Design: Océ Business Services, Maastricht

Cover photo Gabriella Eijsbouts-Jonker

"From Fluids to Chains: crystallization is the process through which fluids are solidified, starting from a nucleus and then growing in a fashion which assumes a regular pattern in a very marked contrast to the boundaries from which it emerged. A process of crystallization thus gives shape to what was previously shapeless, defining and giving significance to elements of the structure. Drawing on this process, our particular understanding of the crystallization of norms suggests a process by which norms take on regulatory effect". Casey\& Scott 2011, "The Crystallization of Regulatory Norms", p. 77"

ISBN: 978-905-681-3734

NUR: 820

All rights reserved. No part of this publication may be reproduced, modified, stored in a etrieval system or made public without the prior written permission of the author or publisher. 


\section{Corporate responsibility, beyond voluntarism}

Regulatory options to reinforce the licence to operate

Inaugural Lecture

Delivered in an informal and abbreviated form at the acceptance of the appointment of Extraordinary Professor Corporate Social Responsibility at the Faculty of Law, Maastricht University

Jan Eijsbouts

Maastricht, 20 October 2011 


\section{Table of Contents}

1. From Practice to Theory, Introduction 6

2. CSR and substance: social norms 10

2.1 The CSR debate $\quad 10$

2.2 CSR characteristics $\quad 12$

2.3 Exploring the Triple P landscape 13

2.4 First conclusion: CSR, a bowl of multiple substantive social norms 15

3. CSR and form: legal pluralism 17

3.1 Introduction $\quad 17$

3.2 The crystallization of social norms; the anti bribery norm as example $\quad 17$

3.3 Second conclusion: CSR, a bowl of multiple regulatory forms 22

4. CSR and Law, oxymoron? $\quad 24$

4.1 Law and morals $\quad 24$

4.2 The voluntary vs. mandatory debate $\quad 25$

4.3 Voluntarism; CSR, criticism on concept and on modality 27

4.3 Third conclusion: CSR neither voluntary nor mandatory, but both 29

5. CSR, norms, practices and foundational underpinning: the licence to operate $\quad 30$

5.1 Distinguishing norm and practice 30

5.2 Two descriptions, CSR as normative notion and CSR as process 31

5.3 Bridging the gap between academia and practice 32

5.4 CSR through the legal lens, corporate citizenship and the licence to operate 34

6. Reinforcing the licence to operate: changing the paradigms in company law $\quad 37$

6.1 CSR and regulation; form following function 37

6.2 Players, rules and tools; an anatomic lesson $\quad 40$

6.3 Corporate governance and CSR intertwined 41

6.4 Smart regulatory policies, nudge, meta-regulation, transparency $\quad 44$

6.5 Company law, changing paradigms in the shadow of CSR 47

6.5.1. Constitutional foundation; the company's interest as pluralist concept 47

6.5.2. Corporate groups and their constitution;

aligning law with economic reality

6.5.3. Multinational enterprise liability; fundamental rights and global remedies 53

7. From Practice to Theory, Epilogue 55

8. Acknowledgements $\quad 57$

Literature $\quad 59$ 
Esteemed Rector Magnificus and Madam Dean of the Faculty of Law, Dear colleagues and students, Dear family, friends and guests,

\section{From Practice to Theory, an Introduction}

In 1971, one year after Milton Friedman dismissed CSR and claimed that the only responsibility of business was to increase its profits, I joined Philips' Corporate Legal Department in my first job as a company lawyer. Although the acronym CSR was virtually unknown in 1971 on this continent, it was the year in which the initial signs of a wakening notion of the CSR concept in the Netherlands could be noticed. As a young lawyer and unaware of Friedman's doctrine, I had to deal with important developments, in 1971, concerning the legislation governing corporations and their activities, which we now would characterize as CSR- or, more practically, Triple Bottom Line or Triple P- (People, Planet, Profit) ${ }^{1}$ inspired. Let me give you a short account on each of these P's.

In the People field the so-called Structure Regime of 1971 codified the stakeholder model in Dutch company law and brought for the first time the labour factor into the structure of big companies by providing the employees with the right to codetermine the composition of the supervisory board. The act also codified case law ${ }^{2}$, which had ruled that the supervisory board should conduct its tasks in the interest of the corporation, which was not the interest of the collectivity of shareholders, and it made major management decisions subject to the supervisory board's approval, thereby securing indirectly the employees' influence on these decisions. In addition, the employees, represented by their unions, could request the Enterprise Chamber of the Amsterdam Court of Appeal to order an inquiry into the management of the company, the outcome of which could result in the court's finding of mismanagement with wide-ranging corrective powers by the court. Finally, the position of labour was reinforced by the new Works Councils Act 1971, allowing the works council to appeal at the Enterprise Chamber of the Amsterdam Court of Appeals against those contemplated major corporate decisions, to be taken against or without the positive advice of the works council, which could affect the position of the workforce. This complex of far

\footnotetext{
John Elkington, "Cannibals with forks - The Triple Bottom Line of the 21st Century Business", Oxford: Capstone Publishing Limited, 1997.

2 Doetinchemse IJzergieterij, HR 1 april 1949, NJ 1949, 465.
} 
reaching new legislation was the result of a long consultation process under the central notion "societal embedding of the enterprise" (my translation of "vermaatschappelijking van de onderneming"). Finally, I mention the heavily debated but not adopted VAD (vermogensaanwasdeling) proposals by the labour unions to let the employees share in the value added to the company's equity in the past financial year.

Also regarding the Planet field important legislation was introduced regulating emissions into the air and discharges of industrial waste into the surface waters. 3 The concerns regarding the environment, sparked by the famous book "Silent Spring" by Rachel Carson, made the Board of Management decide, also in that same year 1971, to establish a high level corporate committee on environmental policies, the "Concerncommissie Milieuhygiene" (in English Group committee Environmental Policy). This committee consisted of senior-executives of the relevant Corporate Departments and, surprisingly, me as the youngest arrival at Legal. Shortly after I had commenced this activity, estimated by the Legal leadership as $5 \%$ of my time, it became clear that at least half of the more than 100 Philips establishments (inrichtingen) in the Netherlands were in need of legal support in obtaining or revising their environmental permits based on the new legislation. This was a massive task bringing lots of negotiating experience in obtaining these legal licences to operate. One of the surprising findings of the committee was that it would be problematic to disclose to the outside world the substantial savings in production costs which Philips' new environmental policy had been able to achieve. We feared criticism from civil society for alleged wrong motives of our new policy, being a narrow profit-related self-interest instead of a sincere concern for the preservation of the environment. The idea, that green policies and healthy profit could go hand in hand and result in a win-win situation, was highly unfashionable at the time.

Concerning the Profit field the dismissal, at the time of my arrival, of one of the senior managers of the Finance Department who had used inside information for personal gain, came as a shock. Although at the time the use of inside information was not regulated in Europe ${ }^{4}$,

3 Wet van 13 november 1969, houdende regelen omtrent de verontreiniging van oppervlaktewateren, Wet van 26 november 1970, houdende regelen in het belang van het voorkomen of beperken van luchtverontreiniging.

4 Kristen 2004. 
the internal Philips rules against such use were very strict. The most striking experience in the Profit field, however, was a litigation I had to manage. We received a writ of summons from one of the most respected Amsterdam lawyers. He represented a Lebanese agent, hired to support Philips in obtaining a contract for a major telecoms project in Jordan. Although the transaction had not materialised, the agent claimed his commission of some millions of guilders asserting that Philips as principal was to be blaimed, because the project was not carried out although full agreement had been reached. Checking the facts I found that the project was to be financed by the Jordanian Government with US development funds. A couple of days before the official signing the Jordanian authorities, however, had cancelled the ceremony. It appeared that the US funds had been withdrawn by the US Government based on a complaint by US competitor AT\&T, that US funds should not be used to finance a project with its non-US competitor Philips. The lawyer argued, that Philips should have sued the Jordanian Government in its courts asking that the government be ordered to sign and execute the contract based on the full agreement having been reached. To my objection that a court order by a Jordanian court to the Jordanian government to proceed with the project was inconceivable, the lawyer responded in all seriousness that it would have been completely normal and accepted in Jordan to bribe and pay the judge and that there were no legal impediments to do so. He obviously didn't share my view that the Dutch courts would have a problem in following his line of reasoning and he appeared quite confident of winning the case. The end of the story was that we agreed, out of court, to reimburse the agent for his costs, which, by the way, we had offered to him already before he started the case. The idea, however, that a company like Philips should bribe a judge to obtain a positive ruling, was appalling to us even if it was not illegal at the time. Law and morals or ethics apparently were two different domains, a theme that has divided legal philosophers and scholars to this day and to which I shall revert later in my lecture.

During my 36-year tenure as a company lawyer many more developments in the relationship between business and society as well as personal experiences in my corporate law advice practice generated a deeper interest in and influenced my thinking about the theoretical underpinnings of law, regulation and ethics in the business context. It inspired me to write an article in 2005 on the legal aspects of CSR, criticising the prevailing approach by governments and business. 5

5 Eijsbouts 2005 . 
Little did I expect at the time, that this "innocent" article would lead to the appointment in the capacity which I accept today with this inaugural lecture. Hence the first reason for the title of this introduction "from Practice to Theory". The second reason is the complementary nature of colleague Sybren de Hoo's lecture and mine. He focused on CSR in practice, or CSP for Corporate Sustainability Performance. My aim today is to try and illustrate why and how law and, in a broader context, regulation is relevant for CSR and, in turn, CSR is relevant for law. This is in particular relevant in view of the still prevailing position of governments and the business community, that CSR is voluntary or "beyond legal compliance", as it is technically termed. The definition of CSR used by the EU Commission reads:

"a concept, whereby companies integrate social and environmental concerns in their business operations and in their interaction with their stakeholders on a voluntary basis". 6

Sybren de Hoo has provided us in his lecture eloquently with ample arguments from an empirical point of view against this "voluntarism". For my part I intend not only to add normative arguments against this "voluntarism", but also to provide ideas for a normative legal and regulatory underpinning to the concept of CSR as a central theme in today's relationship between business and society. ${ }^{7}$ After this introduction I will share with you during my lecture the following topics:

- CSR and substance: social norms

- CSR and form: legal pluralism

- CSR and Law oxymoron?

- CSR; norms, practices and foundational underpinning: the licence to operate

- Reinforcing the licence to operate: changing the paradigms in corporate law

- From Practice to Theory to practice; Epilogue

- Acknowledgements

6 EU definition of CSR: Commission of the European Communities, Green Paper Promoting a European framework for Corporate Social Responsibility, COM (2001) 366 final, Brussels, 18-7-2001. In later policy documents this definition was maintained. See for the Netherlands SER 2000 and SER 2008a

7 Mullerat 2005, entitled "Corporate Social Responsibility, the corporate governance of the $21^{\text {st }}$ century". 


\section{CSR and substance: social norms}

\subsection{The CSR debate}

Let us for a start take a closer look at CSR. What does it address or cover? In a wider context it covers the relation between business and society, which is a multifaceted subject of philosophies, theories, policies and practices in different disciplines. Antony Burgmans, former CEO of Dutch-English multinational Unilever and chairman of the Governmental Advisory Commission on the relation of CSR and Corporate Governance, gave the following description: "CSR in its core is nothing more than decent business (in his Dutch description "fatsoenlijk en netjes ondernemen"), perceived as such by society". ${ }^{8}$ This description contains two relevant aspects. Is CSR's core of decent business conduct all there is to it and can we leave the topic to scholars in business ethics or does CSR contain more than this core and, if so, what should it be? And how does the qualification "as perceived by society" impact on the substance? Will society simply wait and hope for the best leaving important decisions to the market? The basic idea of the CSR concept is that business firms are a vital part of society and that they have both the power and the responsibility to conduct their affairs in ways that satisfy not only shareholders, but also other constituencies such as employees, customers, the environment and the community at large. As recent developments in the field of climate change, the financial and economic crisis, the possible negative impact of business operations on human rights and the environment as well as the rapid depletion of natural resources have shown there is every reason to take a closer look at business' responsibility to contribute to a sustainable future. Is there a role for business in sustainable development, defined as "development that meets the needs of the present without compromising the ability of future generations to meet their own needs"?9

Burgmans' decent business as the core of CSR in itself points to ethical behaviour as such, but is of course insufficiently descriptive as basis for this complex notion which may become clear when I quote the textbook which we used this year for the CSR course in the Master Globalisation and Law:

8 Burgmans 2008; see also Triple Value \& Rinnooy Kan 2008, the research report for Burgmans 2008.

9 World Commision on Environment and Development ("Brundtland Commision") - Our Common Future (1987). 
"The positive and negative impacts that business had on society generated public, political, and academic debate. While it was clear that business sought a profit from providing goods and services in response to society's demands, it was much less obvious what constraints should be put on its activities and who should impose them. Was all profit legitimate? Was all profit legitimate, provided that the company stayed within the law? What was a fair distribution of the wealth business created between shareholders, employees, and wider society? Should companies give part of their wealth back to the communities within which they operate? Could markets be relied upon to set a fair price, whether for labor, products, or natural resources? Could governments reliably decide what was in the public interest?"10

All these questions relate to the substance of CSR and both in academia and in practice these questions have raised much debate and controversy. Major corporate scandals during the last ten years culminating in the current financial and economic crisis have triggered more pointed discussion on the responsibilities of business in general and the financial sector in particular. In Burgmans' description, the business practices giving rise to these developments were certainly not perceived as decent by society. So an avalanche of legal, regulatory and even selfregulatory responses ${ }^{11}$ was the result and many question nowadays whether these reactions are sufficient. The introductory words of the report on the EU Conference "Towards a greater understanding of the changing role of business in society"12, held in 2010, exemplify this by the following statement:

"Public trust in business was shaken as never before and fundamental questions were raised concerning not just the regulation and public accountability of business but also its values, its culture and its relationship with stakeholders. Furthermore, it gave an additional impetus to the trend to redefine the responsibilities of business not as responsibilities to the traditional constituencies of shareholders, employees, suppliers and customers but also to a much broader range of stakeholders at a global level, and indeed, even the physical wellbeing of the planet itself". ${ }^{3}$

\footnotetext{
10 Blowfield Murray 2011, p. 7 .

11 Cf. Code Banken, 9 september 2009 (www.nvb.nl).

12 EU CSR Conference, April 2010 "Towards a greater understanding of the changing role of business in society"; ec.europa.eu/research/social-sciences/events-102-presentations_en.html.

13 Report mentioned in note 12.
} 
This trend, identified at the conference, to redefine the responsibilities of business as including even the physical wellbeing of the planet, would of course lead to an almost impossible task for business to live up to in general and for me this afternoon to consider in particular. It will, however, prompt us certainly to think "out of the box" or, if you will, "out of the lawyer's comfort zone" and, I'm afraid, even "out of the business person's comfort zone".

\subsection{CSR characteristics}

Now, for a start, you would expect of course a definition of CSR. I am asking, however, for your patience, since, as Sybren de Hoo has already illustrated, one of the still heavily discussed issues in CSR is what it actually means. Like corporate governance CSR is still in search of its paradigm. ${ }^{14}$ Depending on the discipline and background of the discussant, academic or practitioner, philosopher, politician, economist, management theorist, sociologist or lawyer, the chosen conceptual foundation of CSR and the preferred definition vary considerably. An analysis of the many ${ }^{15}$, definitions of CSR resulted in the following core characteristics of $\mathrm{CSR}^{16}$, which these definitions for the major part appeared to share ${ }^{17}$ :

- Voluntarism, implying that CSR exclusively covers the domain "beyond the law";

- Internalizing or managing externalities, to account for the total cost of business in the market prices for its goods and services;

- Multiple stakeholder orientation, to balance fairly all impacts of operations on people;

- Alignment of social and economic responsibilities, to balance fairly financial and social benefits;

- Practices and values, to put the CSR practices in the right values context;

- Beyond philanthropy, to adopt CSR as a core function in business strategy and policy rather than as a bolt-on nicety.

My task this afternoon is to address these characteristics through a legal lens and to provide perspectives for governance and law, corporate

14 Tricker 2009, p. 233 and van Oosterhout \& Heugens 2008, p. 197-223, who argue that CSR in its more than 50 years of existence has not been able to establish a reliable scientific framework and hence suggest to forget CSR altogether, since other, well established, frameworks address the issues commonly labelled as CSR.

15 Carroll \& Shabama 2010, p. 89, refer to a study by Dahlsrud in 2006 who identified 37 definitions.

16 Crane, Matten and Spence 2008 , p. 7-9.

17 Cf. also the elements De Hoo has provided as essential elements for a CSR description, De Hoo 2011, p. 15. 
law in particular. To focus on the substance of the CSR norms I return to John Elkington's Triple P concept, mentioned in my introduction: People, Planet and Profit. How can we make this concept operational from the point of view of substantive norms?

\subsection{Exploring the Triple P landscape}

In my introduction I referred already to several examples for each of the three P's. ${ }^{18}$ Let us now take a closer look at society's expectations in each of the three P's:

People in a business context refers first of all to employees and covers such aspects as fair labour and employment conditions, consultation and co-determination on issues which affect the position of the company's most valuable "assets", its employees, and, more and more important in an international context, the safeguarding of a wide range of human rights in an employment context. ${ }^{19}$ Moreover this $P$ relates also to avoiding harm to third parties, which may be affected by the operations of business, so-called indirect stakeholders as Freeman has first mentioned them. ${ }^{20}$ He defines stakeholders as those individuals or groups who may be affected by or may affect the policies and operations of corporations. The most pertinent category of norms to be safeguarded in this context are these third parties' human rights, individually and collectively. We shall look more closely to this category of CSR norms later in this lecture.

Also Planet has two dimensions. It refers to the rapid depletion of essential natural resources, such as the rain forests, water, food (think of fish, palm oil), energy and other vital elements for the planet's future sustainability. Sybren de Hoo showed you not only current global overconsumption but also its highly unequal distribution patterns. Moreover, it covers the protection of the environment. Traditionally, of course, that meant water, air and soil, but already for quite some decades it also means the greater natural systems, which are increasingly affected by human activity such as the climate and the ozone layer.

18 See for an extensive listing of the each of the 3 P elements de Hoo 2011, Annex 1, P 57-59. Another instructive approach is provided by Hoskins 2008, who distinguishes the following CSR elements: community, employment, environment, marketplace, business relationships and human rights, p. 66

19 Van den Heuvel 2009

20 Freeman 1984: stakeholders are persons and organisation who affect or are affected by the coprporation's polices, decisions and actions; primary stakeholders are those stakeholders who are vital for the corporation and without whom the corporation cannot function, the other stakeholders are called secondary stakeholders 
The Montreal Protocol has successfully addressed the latter. A similar result for our climate is still beyond the horizon.

The final P, Profit, relates to the way profit is obtained and reported. Decent business in this context means making a reasonable profit conforming to the basic rules of society, both those embodied in law and those embodied in ethical custom. You may be reminded by this description of the famous (or infamous?) Friedman Doctrine already referred to: a corporate executive's .... "responsibility is to conduct the business in accordance with his employers' (read "shareholders", JE) desires, which generally will be to make as much money as possible while conforming to the basic rules of the society, both those embodied in law and those embodied in ethical custom. ${ }^{21}$ Friedman deviates in two important aspects from my description. Reasonable profit is not as much money as possible and Friedman's basic rules of society are very narrowly conceived. This last $P$ implies above all a sustainable business model based on inter alia fair competition, no bribery and correct profit recognition (no cooking of the books) but also fair disclosure.

According to John Elkington's claim, the overarching remit of CSR is the requirement that business strikes the right balance between the three P's. This balance has two dimensions: the dimension of a fair cost allocation among the stakeholders and the dimension of a fair distribution of the business results among the stakeholders. Here we touch on the CSR characteristics: internalizing or managing externalities, multiple stakeholder orientation and alignment of social and economic responsibilities, which I mentioned before. ${ }^{22}$ We shall later turn to these characteristics in the context of law and regulation and in particular the assurance of "do no harm", a negative connotation, and "wealth creation and distribution", a positive connotation. This resonates with two of the main functions of law and regulation, the protective function on the one hand and the enabling function on the other hand. ${ }^{23}$

21 Friedman 1970.

22 See p. 12.

23 In his article "The future of legal theory" Zumbansen distinguishes 5 roles or functions of law: "Law as an institutionalised system of rule enforcement, Law as a means of stabilising expectations, Law as a means of oppression, Law as hope, Law as an empty shell-without (proper) method, heart or soul ...? The first definition demands a particular framework in order for something to be called 'law'. It refers to the institutionalisation of creating, implementing and interpreting law. Law is thus removed from other rules and behaviour-governing norms such as religious beliefs, ritual rules, or 'social norms'”. Zumbansen 2011, page 327. 


\subsection{First conclusion: CSR, a bowl of multiple substantive social norms}

What should the general conclusion be about the substance of the CSR norms and their identification? First of all, that there is no such thing as a "one size fits all" substantive notion of CSR. From a substantive point of view CSR is a container of multiple social norms relating to a whole series of topics and issues in the Triple P field, which may vary not only among different industries but also in time and place, not least due to the perceptions of society (or better put societies) as rightfully observed by Antony Burgmans. These perceptions are by their nature subject to constant change with the evolution of business, advancement of technology, and not least the emancipation of civil society actors. This all has become more clear and pressing since the unanimous endorsement by the UN Human Rights Council of the Protect, Respect and Remedy Framework proposed in 2008 by the Special Representative of the UN Secretary General on the issue of human rights and transnational corporations and other business enterprises, Harvard Professor John Ruggie. ${ }^{24}$ Ruggie clearly distinguished and specified the state duty to protect and the corporate responsibility to respect human rights. This corporate responsibility to respect human rights is not a legal responsibility as Ruggie posits, but a "universal baseline expectation" from society, so an uncodified social norm. The third pillar of his framework relates to adequate remedies, both judicial and non-judicial. ${ }^{25}$ Among the latter he emphasized the importance of company grievance procedures for stakeholders, including mediation. In June of this year the equally unanimous endorsement of his Guiding Principles for the implementation of his Framework by the Human Rights Council followed. ${ }^{26}$ In the analysis leading up to this framework, Ruggie had identified a very broad range of instances, in total over 300, in which corporations had violated, or assisted in the violation by states, of human rights. ${ }^{27}$ His Guiding Principles 2011 specify how corporations should live up to their responsibility to respect human rights. The key-word is "risk based due diligence": corporations should on a continuous basis assess, whether and in what ways their actual or intended operations run the risk to impact on the human rights of others and take preventive or remedial steps. This assessment of the relevant substantive CSR norms is a process of contextualization: each company will have to

\footnotetext{
24 Ruggie 2008, Pitts \& Sherman 2008.

25 Rees 2008.

26 Ruggie 2011.

27 Ruggie 2008, Schweisfurth 2011.
} 
analyze its position based on its specific industrial characteristics and the given societal context and this in a continuing dialogue with the relevant stakeholders in that same context. An oil company obtaining or using a production licence in an agricultural or forest region in a developing country has a different CSR profile than when it obtains and/or uses a production licence in deep waters. And this in turn is quite different from a pharmaceutical company opting to do its clinical testing in a developing country rather than in its home country. An IT company, in turn, has a different CSR profile when it opts to outsource its production to a developing country than when it sells an internet access system to a country with a totalitarian regime. Sybren de Hoo provided in his lecture tools for this CSR assessment process in general. In addition, ten Dutch multinationals participated in 2010 in a UN Global Compact Dutch Chapter project to test the implementation of Ruggie's Framework relating to human rights in particular. The resulting tool was well received by the UN Human Rights Council.28

28 How to do business with respect for human rights, a guidance tool for companies. available at www.genetherlands.nl. 


\section{CSR and form: legal pluralism}

\subsection{Introduction}

Having explored the substance of the CSR norms, let us now address the form in which these norms can manifest themselves. Substance and form for lawyers are two important if not essential notions. Let me illustrate this distinction with an example. In my introduction I mentioned the court case of the Lebanese agent against Philips: the issue was whether we should bribe the judge in order to pursue our business goals and secure the agreed transaction. Bribing foreign officials at the time - we are speaking of the early seventies of the latest century - was not illegal, but it was and still is highly unethical according to our social norms: you simply don't bribe, so the substance of the norm is clear. Bribery, however, is a widespread evil with far reaching consequences for the ideal of justice and fairness. As recent examples have shown, even well regarded multinationals, such as Siemens, ABB, BAE and Philips among many others, still cannot control all of their employees in their quest for the best deals. At the recent OECD/G2O anti-corruption conference 29 OECD Secretary-General Angel Gurría stated that the total amount of bribes paid worldwide is estimated to be not less than $5 \%$ of global GDP!30

\subsection{The crystallization of social norms; the anti bribery norm as example}

Let me give you a picture of society's reaction to this phenomenon since our Jordanian telecoms case in the early seventies of the last century, when bribery of foreign officials was not regulated at all. Also in those days, multinationals were not always considered good corporate citizens, another CSR inspired term as we shall see, and the public cry for more regulation was loud and clear. When in 1976 the member states of the OECD, a so-called Intergovernmental Organisation or IGO, reached agreement on a Declaration on International Investment and Multinational Enterprises ${ }^{31}$ providing for protection of the international investments by multinationals, it was felt that the other side of the coin, decent behaviour as quid pro quo, should also be

29 Conference organised by the OECD in cooperation with G20 chair France on 27-28 April 2011 in Paris.

30 Another striking figure produced by an OECD study is the average $10 \%$ increase in prices for products and services world wide as a consequence of violations of antitrust laws.

31 The Declaration on International Investment and Multinational Enterprises.This Declaration was adopted by the Governments of OECD Member countries on 21 June 1976. It was reviewed in 1979, 1984 and 1991. 
addressed. It was the push for the OECD member states to agree also on the first edition of the OECD Guidelines for Multinational Enterprises as a complement to the Declaration. ${ }^{2}$ These guidelines are widely considered the first comprehensive international CSR instrument, dealing with such issues as disclosure, competition, financing, taxation, employment and industrial relations, environmental protection, science and technology. These topics were preceded by general principles. Principle 7 read: multinational enterprises "should" not render - and they "should" not be solicited or expected to render - any bribe or other improper benefit, direct or indirect, to any public servant or holder of public office. Mind the word "should" in this principle. One would expect here the word "shall" as imperative, but the OECD member states had committed to each other to only recommend to their multinationals to abide by the OECD Guidelines. So they were non-binding. In legal jargon this is called "soft law". There are various definitions of soft law, but all of them share the common characteristic that as statements or declarations by organisations of states or international governmental organisations they represent authoritative opinions on principles and practices that may have legal effect. 33 This legal effect may be twofold. It may assist the national courts in their interpretation of national law for instance in the application of so-called open or blanket norms. It may also assist legislators, international and national, in their design of future legislation. So for the first time the substantive norm "don't bribe foreign officials" was codified, albeit not in a legally binding way, but with possible legal effect. 34

Inspired by the fight against corruption that had surfaced in international business by American multinationals in the defence and aviation industry - the name Lockheed may ring a bell - only one year later, in 1977, the US enacted the so-called Foreign Corrupt Practices Act (FCPA),35 hard law by which bribery of foreign officials became a crime. As a complement, the act provided for an

32 OECD Guidelines for Multinational Enterprises, Recommendations for Responsible Business Conduct in a Global Context, OECD Ministerial Meeting 25 May 2011, p. 29.

Available at: $h t t p: / / W w w . o e c d . o r g / d a t a o e c d / 43 / 29 / 48004323 . p d f$; see also van Eyk 1995

33 Senden 2005, Barkhuysen \& van Emmerik 2010, Calliess \& Zumbansen 2011, p. 255-260

34 As an example in the People sector of CSR, the Dutch Enterprise Chamber based one of its judgments on the public adoption by a multinational of the OECD Guidelines. In their successfull appeal by the employees against the multinational's decision to close a plant in Amsterdam the court paid attention to the fact that the multinational had not applied the principle of due consultation of the OECD GuidelinesOK 21 juni 1979, NJ 1980, 71 (Batco, m.nt. Maeijer).

On this case see Timmerman 1988

35 The Foreign Corrupt Practices Act of 1977, as amended, 15 U.S.C. $\$ \S 78 d d-1$, et seq. 
obligation to maintain adequate records of all payments to foreign officials in their accounting books to enhance transparency and reinforce compliance. ${ }^{36}$ so from the OECD Guidelines for MNC's, a soft law arrangement, the substantive norm "don't bribe foreign officials" had migrated in the US to the hardest law possible, criminal law with an administrative law complement aiming at better governance. Full compliance with the FCPA as stipulated by the US Department of Justice requires that companies as principals provide in their agreements with agents that they shall not bribe foreign officials in their activities on behalf of the principal. So contract law also enters the regulatory landscape for bribery. This is different from normal contract law in the sense that it is used also as a regulatory tool. 37

Interestingly, substantive norms can also migrate, in whole or in part, from a more strict form of regulation to a less strict form or even back to no regulation at all, so-called deregulation. In the case of bribery of foreign officials as sanctioned in the FCPA this happened in 1989, after it had become apparent, that the FCPA put the US companies in a disadvantageous position towards their non-US competitors with respect to so-called "facilitation payments", small payments to low officials to make them perform their duties, such as allowing foreigners or imported goods to enter their country. In 1989 the FCPA was amended to exclude these facilitation payments from the crime of bribery, although facilitation payments should still be accounted for in the books and records.

The fight against corruption took a different direction in 1993 with the foundation of Transparency International by Peter Eigen, former director of The World Bank. TI is a so-called Global Action Network, the name assigned by CSR best practices pioneer Steve Waddell to a set of multiple public private networks in various CSR fields. Transparency International is a network counting today 120 country chapters. ${ }^{38}$

36 The so-called books and records and internal controls rules, monitored and enforced by the US Securities and Exchange Commission.

37 Eg the difference between commercial agreements and regulatory agreements, Cafaggi 2011. This form of contract is a mixture: the agency contract as such is of a commercial nature, but the required compliance provisions will give them a regulatory touch.

38 See Waddell 2011 for an indepth anaysis of the origin, background and working of Global Action Networks as instruments of self- or co-regulation of CSR initiatives between public and private (both business and civil society) actors. See SER 2008b on International CSR for a Dutch example of a Global Action Network. 
Since the US multinationals were still hampered by the FCPA obligations in their competition with non-US multinationals in foreign countries, the US government kept insisting that other countries should adopt similar legislation to create a level playing field. They targeted in particular the OECD and in 1997 the OECD Convention Combating Bribery39 was signed, a treaty which obliged the signatory states to implement FCPA type provisions in their respective criminal and administrative laws. Conventions or treaties like this OECD Convention bind the signatory states, but in principle not their people and companies, unless and until the states implement the agreed principles and rules in their national legislation. ${ }^{40}$ As a result of the implementation of this convention, bribery and for the most part also facilitation ${ }^{41}$ of foreign officials became criminal law violations in the Convention's signatory states. There has been still one difference in reach between the US and the other OECD Convention countries: the US apply their criminal and administrative anti-bribery provisions not only to US corporations operating abroad, but also to non-US corporations with a link to the US. That type of extraterritorial effect has not been adopted by the other OECD Convention states, except for the UK, which implemented the Convention only this year, but then in an even more strict and expansive way than the US. 42

This is however not the whole story on the travels of the substantive "no-bribery" norm through the regulatory landscape. I shall not deal with all regulatory international instruments which have embraced this substantive norm 43 , but from a regulatory point of view there are a couple of additional interesting forms that deserve mentioning. In 1999 two Council of Europe Conventions on Corruption, one on criminal law and one on civil law, were signed. 44 The latter one is particularly interesting, since it stipulates that the Council of Europe member states

39 Convention on Combating Bribery of Foreign Public Officials in International Business Transactions, adopted by the Negotiating Conference on 21 November 1997 (www.oecd.org/documents).

40 It goes beyond the scope of this lecture to dwell on the different ways national jurisdictions treat international law (differences between monist or dualist systems and the recognition of international customary law by law or by the courts), but it is relevant in the context of CSR. See also Triggs 2006.

41 Interestingly, the Convention left the facilitation exemption at the discretion of the member states, but the majority of them decided not to exclude facilitation from the crime of bribery, so in this respect the US multinationals are now in a more favourable position.

42 The increasing number of countries applying their national laws to conduct by foreign nationals (including foreign corporations) outside of their territory on an extraterritorial basis causes collision between these jurisdictions, which all regulate the same bribery of foreign officials. In extraterritorially applied criminal law there is no such thing as an international principle of "ne bis in idem".

43 See for a comprehensive review of the regulation of bribery Lambooy 2010, Chapter 5. 
shall provide in their civil legislation for compensation of damages that persons, both natural and legal, have sustained as a consequence of corruption. 45

In the last quarter of the last century new forms of international instruments were developed on a tripartite basis: governments or IGO's, NGO's and business and relevant sectors of civil society. 46 The primary examples are the Tripartite ILO Conventions of 1977. A tripartite initiative, in which bribery was addressed, was the UN Global Compact of 200047 , mentioned by Sybren de Hoo already. It is a non binding instrument, which can be voluntarily adopted by companies and which in 2000 covered in nine principles the substantive CSR topics human rights, employment and environment. Corruption was later added as a tenth principle. Companies, which join the Compact, declare that they will improve continuously in the fields of the principles and publish yearly their Communication on Progress (COP). From a regulatory point of view this is an example of self-regulation: companies decide to join voluntarily, but once they have joined they are subject to the Compact's compliance obligations: it requires specific action programs on each of the 10 principles and yearly disclosure through the COP's. In the same vein as soft law, self-regulation may have legal effect, though not necessarily on the same legal basis. 48

Finally, I should mention the UN Convention Against Corruption of 2003.49 This convention has the broadest scope both in terms of territorial reach since it was signed by 140 states and ratified by more than 107 states and in terms of substance. The convention covers both corruption of officials and private persons and requires the states to adopt the offence of bribery in their criminal law and provide for compensation of civil damages to persons affected by bribery.

44 Council of Europe, Civil Law Convention on Corruption, 4 November 1999 and Council of Europe, Criminal Law Convention on Corruption, 27 January 1999; see in respect of the former also Civil Law Convention on Corruption (ETS No. 174) 4 XI 1999, Council of Europe, Explanatory Report, http://conventions.coe.int/treaty/en/treaties/html/174.htm

45 In her winning essay for Hiil's 2011 law of the Future Conference Abiola Makinwa analyses the efficiency of public and private regulation to combat bribery. Makinwa 2011.

46 See for an extensive overview on many subjects and in many industries, Waddell 2011.

47 UN Global Compact: www.unglobalcompact.org/AboutTheGC/TheTenPrinciples/index.html.

48 In his case against Nike, a Californian student-activist, Mark Kasky claimed that Nike had not complied with its public statements that the production processes of their products would be free of child labour. In his research, however, Kasky had found child labour in Nike's supply chain and he claimed damages in court based on unfair and deceptive practices under California's Unfair Competition Law and False Advertising Law by Nike, which the courts accepted. A long series of appeals followed and the case settled on the eve of the US Supreme Court's hearing. US Supreme Court: Nike v. Kasky, 26 Jun 2003

49 UN Convention against Corruption 2003: http://www.unodc.org/unodc/en/treaties/CAC/index.html. 
So since 1976, when it left the area of non-regulation and was first codified in the OECD Guidelines on Multinationals, the substantive social norm to not bribe foreign officials thus found its way in various types of regulation: (individual or collective) self-regulation, soft law, civil law, administrative law and, finally, criminal law. It travelled many international and national routes ending in many instances in the strongest form of regulation, criminal law, which by its nature is national state law, although the extraterritorial effect enlarges its reach beyond state boundaries. 50

\subsection{Second conclusion; CSR, a bowl of multiple regulatory forms}

My second conclusion is, that a substantive social norm can leave the territory of non-codified social norms and migrate back and forth among different forms of regulation and even return to the territory of noncodified social norms.

The following picture of concentric circles (p. 23), ranging from uncodified social norms as CSR's core (or Burgmans' decent business) via selfregulation and soft law to the different forms of hard law, show the dynamic field of the possible regulatory spaces for the substantive CSR norms: from Burgmans' decent core, literally in the centre, the norms may migrate and crystallize ${ }^{51}$ into a form of regulation which renders an increasingly more stable basis to the norm, from self-regulation and soft law to different forms of hard law, first to provide transparency, then to condition corporate behaviour and, if those means do not avoid harm to third parties, first adequate remedies in civil law, followed in serious cases also by fines and prison.

The distinction between substance and form is therefore also relevant in the CSR debate as the example of bribery shows. So not only in terms of the substance of the CSR norms, but also in terms of the regulatory form into which these norms can crystallize, CSR must be considered a container. The anti-bribery example did shed light on the possible motives and processes that underlie these migration moves.

50 Kristen 2010, IBA 2008.

51 The term "crystallization" is borrowed from D. Casey and C. Scott. See their highly topical article "The Crystallization of Regulatory Norms". It was written in the context of the Transnational Law and Private Actors project of the Hague Institute for the Internationalization of Law HiiL. They clarify: "Crystallization is the process through which fluids are solidified, starting from a nucleus and then growing in a fashion which assumes a regular pattern in a very marked contrast to the boundaries from which it emerged. A process of crystallization thus gives shape to what was previously shapeless, defining and giving significance to elements of the structure. Drawing on this process, our particular understanding of the crystallization of norms suggests a process by which norms take on regulatory effect". Casey\& Scott 2011, p. 77 


\section{The Concentric Circles of CSR Regulation}

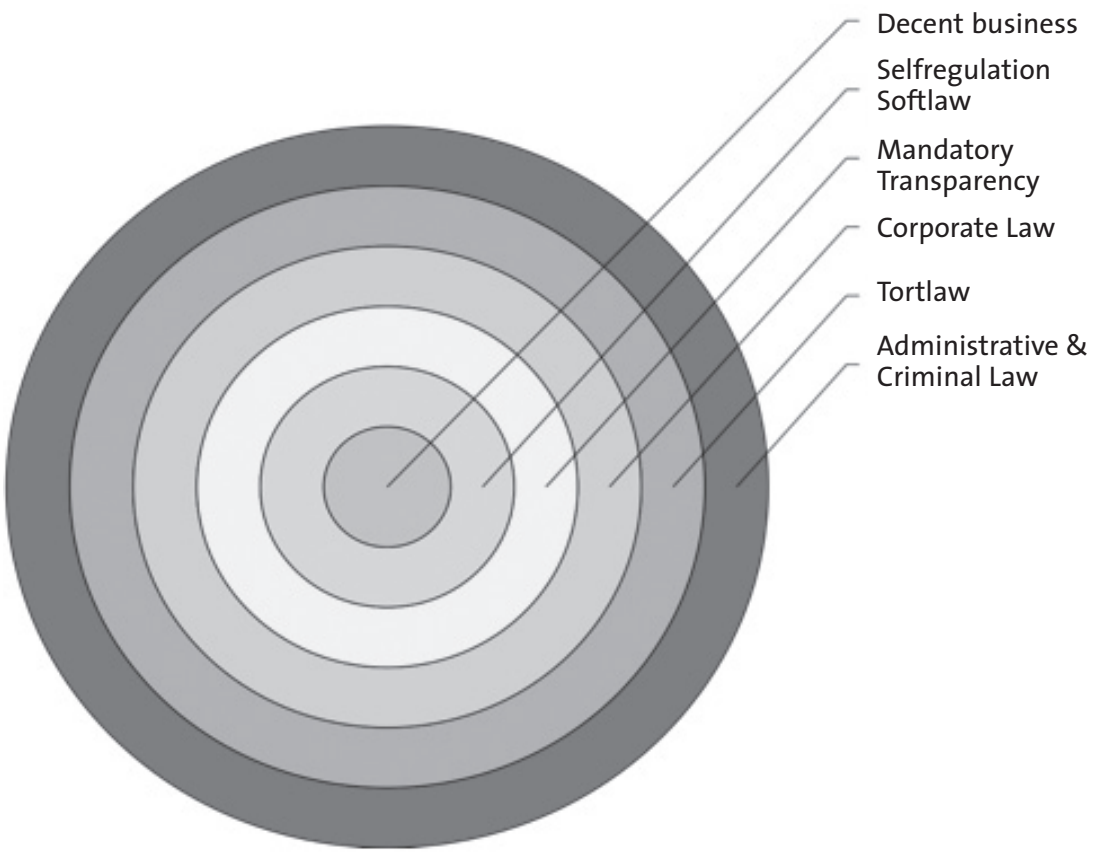




\section{CSR and Law, oxymoron?}

\subsection{Law and morals}

Leading legal philosopher Ronald Dworkin starts the introduction, called "Law and Morals" to his book "Justice in Robes" with the following illustrative anecdote:

"When Oliver Wendell Holmes was an Associate Justice of the Supreme Court he gave the young Learned Hand a lift in his carriage as Holmes made his way to the court. Hand got out at his destination, waved after the departing carriage, and called out merrily, "Do justice, Justice!". Holmes stopped the cab, made the driver turn around, and rode back to the astonished Hand. "That's not my job!" he said, leaning out of the window. Then the carriage turned and departed, taking Holmes back to his job of allegedly not doing justice." 52

In my introduction I mentioned the scholarly divide about the relation between law and ethics or morals. Holmes, one of the famous US Supreme Court justices in the beginning of the last century was a prominent forerunner of the American legal philosophic school of so-called "legal realism". Court decisions based on the facts in the concrete case and not legislation, let alone theories of law, are the most important source of law, "made by the judge on the spot". Similarly as in the so-called legal positivism school of thought there is no link between law and morals. 53 Dworkin, however, has argued for many years that in many circumstances moral facts figure among the basic truth conditions of propositions of law and in his book critically discusses the rival claim: analytical doctrinal positivism, which holds that as a conceptual matter moral facts cannot figure among these basic truth conditions.54 CSR as set of social norms is of course based on justice and fairness and resonates with natural law. Natural law theorists take universal moral principles as basis for any legal system, which next to legality claims legitimacy. For legal positivists or legal realists, who consider morals as something "beyond law" CSR by definition belongs to the territory "beyond law".55 The divide

52 Dworkin 2005, p. 1.

53 For legal positivism, see Hart 1961

54 Dworkin 2006, p. 225 and chapters 6 and 7.

55 "The jurists who believe in natural law seem to me to be in that naive state of mind that accepts what has been familiar and accepted by them and their neighbors as something that must be accepted by all men everywhere." (Holmes 1897,p. 41). See also Teubner $2009 \mathrm{~b}$, dealing with the legal paradox, "justice begins where the law ends" and the question "is it lawful to apply the distinction between lawful and unlawful to the world?". 
between legal positivism and natural law with its basis in universal morality has been bridged in contemporaneous western democratic legal systems, which have adopted moral values in the form of fundamental rights secured by the constitution. These fundamental rights protect the citizens "vertically" against the state but they have also "horizontal effect" between the citizens, who should respect the fundamental rights of their fellow citizens What does this theoretical expose mean for CSR and law? It means that not only philosophically but also in practice law is important for CSR, since its social norms or morals may crystallize in law without losing their moral content.

\subsection{The voluntary vs. mandatory debate}

So far we have reached a couple of important conclusions. First of all, from a substantive point of view CSR is not one single norm, but a container of multiple substantive norms covering a wide range of business activities. Second, as we saw in the context of anti bribery, like any social norm a substantive CSR norm can, but need not necessarily, crystallize into one or more of multiple forms of regulation all the way up to the most strict form of regulation, criminal law. And, in a deregulation move, it can even migrate all the way back to the domain of no regulation at all, as we saw with the phenomenon of facilitation payments and as became painfully clear in the field of financial regulation, which is generally considered to be the main cause of the financial, economic and currency crisis. 56

When we combine the findings on the substance of the CSR norms and the different forms of regulation into which they can crystallize, it becomes clear that the voluntary vs. mandatory debate in fact is a nondebate. First of all, since CSR is no single norm, there is no point in debating, whether CSR as such should be either voluntary or mandatory.57 That discussion can be held with respect to each of the substantive CSR norms in the container separately and in an overwhelming number of instances in all three Triple P-sectors that has already happened with the result that he social norm indeed crystallized in some form of regulation. ${ }^{8}$ But more importantly, the voluntary vs. mandatory debate does not relate to the substance, but to the form, or put more straightforward, not to the "what", but to the "how".59

\footnotetext{
56 Reich 2009,p vii-xi, reporting on Greenspan's hearing by US congress.

57 I herewith clearly deviate from colleague Bas Steins Bisschop, who has argued that CSR as such is a legal norm, capable of being enforced in company law by certain stakeholders (Steins Bisschop 2004)

58 Eijsbouts e.a., 2010, par. 3

59 Lebano 2009; Gunningham 200860 Vranken 2006, Lokin 2007
} 
Two additional arguments, one of a philosophical nature and one of a more practical nature, may support my claim to dismiss the view, that CSR-norms intrinsically are voluntary in nature and limited to the "domain beyond the law". The philosophical one is the fact that the substance of the norm does not change, if it migrates from the voluntary domain to one of the semi-legal or legal domains. The moral or ethical content of the norm stays the same. The second, more practical reason is the simple fact, that there is no hard and fast rule on the boundaries between both domains. That becomes clear when we take a closer look at the notion of law, both in a national and in a globalisation context. On the national dimension, due to the ever more complex nature of society and its regulation, law has developed over the last centuries into a complex set of principles and rules. It is no longer the clear and simple set of codified rules, or in the case of common law, precedents in the form of the courts' rulings. In order to allow for greater flexibility legislators have adopted the strategy to provide for so-called open or blanket norms, allowing the courts to take into account the broader principles or changing societal opinions in the matters before them. ${ }^{60} \mathrm{I}$ mention the concepts of good faith, reasonableness and fairness, good management, mismanagement, evidently improper management and societal opinions (verkeersopvattingen). ${ }^{61}$ These open norms, which are of various different natures and serving different purposes, are relevant in the interpretation and application of the law by the courts in the field of contract and tort law, corporate law, administrative law, criminal law and even international law. Since this interpretation is mostly contextually determined in each case before the courts, it is not possible to provide a hard and fast rule on the demarcation line between the two domains "law" on the one hand and "beyond law" or "non-law" on the other hand. ${ }^{62}$ Globalisation has further complicated this aspect. The nation state is no longer the main source of legal norms and the traditional combination of national and international law is no longer fit for purpose to regulate supranational or cross border relations and corporations are not (yet) acknowleged as subjects in international public law. ${ }^{63}$ Hence the development of the concept of transnational law, introduced by Philip Jessup in his famous lecture Transnational Law at Yale Law School in 1956. ${ }^{64}$ For Jessup Transnational Law consists of the norms that govern

60 Vranken 2006, Lokin 2008.

61 Rogmans 2007, Giesen 2007.

62 In his 2007 preadvice for the Dutch Association of Jurists NJV on alternative regulation Giesen analyses the binding effect of alternative regulation and its role in formal law interpretation in Dutch law, par 3 \& 4 .

63 Nijman 2005.

64 Philip Lessup 1956. 
border-crossing transactions of both public - i.e., governmental - and private - i.e., individual, collective, commercial or other - actors. ${ }^{65}$ Transnational law, also referred to as the new Lex Mercatoria, comprises a broad set of principles, norms and customs which may gain legal effect through both traditional legal instruments such as treaties, conventions and contracts but also through codes and trade customs and practices. ${ }^{66} \mathrm{~A}$ good example is the privately organised internet architecture under the aegis of ICANN, the Internet Corporation for Assigned Names and Numbers. ${ }^{67}$ In their recent pioneering and highly instructive book, laying out a theory and methodological approach of transnational private law, Calliess and Zumbansen gave this approach the title Rough Consensus and Running Code or "RCRC", building on the concept of norm creation that was developed first in the context of the internet standards, a dynamic process of consensus building and code evolution. ${ }^{68}$

This finding of the importance of societal opinions or social norms, both in national law, public international law and transnational law69, is of course of particular interest in the context of CSR as one of the institutional linking pins between society and business. It confirms again that there is no hard and fast rule to demarcate the boundaries between "law" and "non-law".

\subsection{Voluntarism; CSR, criticism on concept and on modality}

Before concluding this chapter, I offer a couple of observations relating to the voluntary vs. mandatory debate on CSR. CSR as a concept has to cope with two forms of criticism. Their proponents reject CSR for opposite motives. The first one can be summarized by the Friedman doctrine already mentioned: the responsibility of business is to maximize its profits in the interest of its owners, the shareholders. Voluntary CSR is a breach of the fiduciary duties of management vis a vis their shareholders. Mandatory CSR a fortiori is out of the question. To summarize this view: "CSR is sacrificing profits in the social interest", the most succinct disqualifier for CSR I found. $7{ }^{\circ}$

65 Calliess \& Zumbansen 2010, Ch 1, p. 11-26

66 Lambooy, Raic, Krycka 2009.

67 ICANN was formed in 1998. It is a not-for-profit public-benefit corporation with participants from all over the world dedicated to keeping the Internet secure, stable and interoperable. It promotes competition and develops policy on the Internet's unique identifiers.

68 Calliess \& Zumbansen 2010, p. 24, also Glinski 2007.

69 Calliess \& Zumbansen 2010, p. 248-255 on Law and Social Norms.

70 Elhauge 2005 , cited in Reinhardt 2008, p. iii. The definition suggests a plain rejection of CSR, but that would be jumping to conclusions as Reinhardt and colleagues explain in their article, in which they take this definition as starting point in their analysis of CSR through an economic lens. 
At the other end of the spectrum we find the critics who reject CSR, either altogether because of its conceived voluntary and therefore counterproductive nature or, acknowledging the pluriform nature, simply in its voluntary fashion. One of the most vocal and influential current academic thinkers representing the former side is Robert Reich. In his seminal book under the suggestive title Supercapitalism ${ }^{71}$ he refers to CSR as an earnest and sincere movement and acknowledges that some of the practices, such as corporate codes of conduct may have a positive impact, "but almost all has occurred outside of the democratic process. Almost none has changed the rules of the game. To view it as a new form of democratic capitalism is to fail to understand the logic of supercapitalism. It is also to divert attention from the more difficult but more important job of establishing new rules that protect and advance the common good, and keep supercapitalism from overwhelming politics." Reich contends that business' mission, in line with Friedman's doctrine, is to maximise profits and that "corporate executives are not authorized by anyone least of all by their consumers or investors - to balance profits against the public good. Nor do they have any expertise in making such moral calculations. That's why we live in a democracy, in which government is supposed to represent the public in drawing such lines".72 Therefore, in view of its proclaimed voluntarism Reich dismisses CSR altogether. Unless democratically established regulation forces business to act in socially responsible ways thereby creating the level playing field for all, demands from customers for the lowest prices and investors for the highest returns will result in fierce competition and "a race to the bottom". Reich's views that only mandatory rules will do the job are for the most part shared by NGO's active in the field of CSR, who, however other than Reich, do not dismiss CSR as a concept, but insist on its mandatory fashion. As I have argued, CSR is not one single norm and it is composed of a wide range of social norms, a number of which, though not all, can crystallize in one or more forms of regulation and, as I have shown, indeed many have done so already. The question would be, how Reich would view CSR if it were no longer characterized as purely voluntary, but as a regulatory mix as I have done today. Another comment I would like to make, relates to Reich's claim for supremacy of democracy. It concerns the lack of global democracy. His analysis stops at the US borders and does not provide the solution to regulate foreign multinational companies, although 
quite a few US CSR related laws and regulations with extraterritorial effect may impact seriously non-US multinationals under US democratic principles.73 Another interesting aspect, although not for today.

\subsection{Third conclusion: CSR neither voluntary nor mandatory, but both}

My third conclusion can be brief: both claims, for voluntarism and for mandatory CSR, relate to form and not to substance and are ideologically driven. As Sybren de Hoo has already amply argued for practical reasons, the paradigm on voluntarism should change. This characterization is no longer fit for purpose. The real discussion should be, whether and, if so, into what form of regulation each of the substantive CSR norms could crystallize best to achieve the result needed at the particular time and place for the specific norm.

73 I mentioned already the US FCPA. Other examples are the US Antitrust and Securities legislation (for the latter in particular the Sarbanes Oxley Act 2002 and the Dodd Frank Act 2010) and the Alien Torts Statute of 1789 . I shall refer to these later in my lecture. 


\section{CSR, concept, practice and foundational theory: the licence to operate}

\subsection{Distinguishing norm and practice.}

Having explored the substantive nature of the CSR norms and the different forms into which they can crystallize and moreover having dismissed the claimed voluntary nature of CSR, I would now submit that there is a reason and indeed need, not only first, to distinguish between two dimensions in the concept of CSR: a normative dimension and an operational or process dimension to put the norms in practice, but also, second, to structurally link the two. Why is this important? Not only does it put Sybren de Hoo's lecture and mine in perspective, but as the report on the EU CSR Conference of 2010 confirms, there is "a very big gap between the goals of the European Commission (which saw CSR as a vital link between innovation and competitiveness on the one hand and social inclusion on the other) and, with a few exceptions, the perceptions of scientific CSR academics". In respect of CSR research, the report finds that there are a number of weaknesses, such as fragmentation and lack of collaboration with little integration of theoretical and applied work and low interdisciplinarity.74 I would assume that this is one of the reasons, why there are many different definitions of CSR in the first place, which represent the many views prevailing, and that these definitions mix the foundational and philosophical normative views on the nature of CSR with the ideologically framed practical views on how to arrive at the desired results in practice. 75 This is reflected in the list of core characteristics of CSR which I mentioned earlier and in the most recent CSR definition, that of the ISO 26000 Guideline. ${ }^{76}$ The clear normative characteristics are the ones that relate to the substance of CSR: internalisation or management of externalities, multistakeholder orientation and alignment of social, environmental and economic responsibilities. The operational characteristics are related to how to best comply with the normative requirements such as voluntarism, or not, and the extension to philanthropy. A special word is needed on the characteristic: mix of practices and values. "CSR is clearly about a particular set of business practices and strategies that deal with social issues, but for many people it is also something more than that - namely

74 See EU Conference Report, mentioned in note 12,

Chapter 1 , second page, under CSR research in practice.

75 Lebano 2009.

76 ISO, the International Organization for Standardization, has launched an International Standard providing guidelines for social responsibility (SR) named ISO 26000 or simply ISO SR and waS released on 1 November 2010 
a philosophy or set of values that underpin these practices...... The values' dimension of CSR is part of the reason why the subject raises so much disagreement - if it were just about what companies did in the social arena, it would not cause so much controversy as the debate about why they do it."77

\subsection{Two descriptions, CSR as normative notion and in operation}

This shows in my opinion, why there is a need to separate the notion of "what" or in this context better even "how" from the notion "why". "Why" refers to the normative aspect, "how" refers to the process. This was exactly my reason to propose the following two descriptions in my internal company practice. ${ }^{78}$ With some further refinement, since I developed these two descriptions some seven years ago 79 , I provide the current versions.

My normative description reads: "CSR is the responsibility of corporations to meet the legitimate expectations of society for the firm ${ }^{80}$ to conduct its businesses in ways that produce economic, social and ecological benefits to relevant stakeholders and society at large".

The normative characteristics: multiple stakeholder orientation, alignment of social and economic responsibilities and internalisation or management of externalities ${ }^{81}$ are clearly included around Burgmans' central claim of society's perception on the decency of business management, reflected in legitimate expectations. As we already concluded, some of these expectations are embodied in hard laws, to be enforced by the courts of law, others in "soft laws", self-regulation or in general unwritten ethical values, to be enforced either by the courts of law (e.g. in interpreting open legal norms) or the courts of public opinion.

My operational or process description reads: "CSR as a process is the structured and systematic approach by which firms are embedding all aspects of the applicable CSR- norms in their daily operations at all relevant levels, monitoring compliance and results and reporting to relevant stakeholders and society at large".

77 Crane, Matten and Spence 2008 , p. 8

78 Eijsbouts 2005, p.77. This also resonates with the findings on the need felt by CSR managers for a workable definition of CSR in practice. De Hoo 2010 e.a.

79 Eijsbouts e.a. 2010.

80 Note that I am speaking here about "firm" rather than "company", to reflect that the norms are directed at each form of business organisation, whether or not it is conducted in a legal form.

81 See Sjåfjell 2010 on internalizing externalities. 
Key elements here are identification of the applicable substantive norms, awareness and embedding, measurement, transparency and accountability. This resonates with the definition provided by Elkington as referenced by Dommerholt and mentioned by Sybren de Hoo in his lecture: Corporate Sustainability Performance. 82

\subsection{Bridging the gap between academia and practice}

My submission is that the two definitions, CSR and CSP, can function as the two bridgeheads that will allow us to bridge the gap between the academic research and the practice in the field of CSR. ${ }^{83}$ To illustrate this claim I invite you to join me on a brief excursion to the different fields of scholarship and philosophy, which each have explored the various aspects of CSR from their point of view, aimed in all modesty of course at "a theory of CSR" through a legal lens.

However, before starting this excursion, there is an important caveat to be made. It draws on the origins of the notion of CSR. How surprising this may sound to you, CSR is basically a US corporate law and governance issue. The acronym CSR allows us to grasp the roots of its notion: Corporate Social Responsibility is about the responsibility of corporations towards society. This goes to the heart of corporate law: what is a corporation in law and what responsibilities does it owe and to whom, if any? We shall deal with that important question later in detail, but here I shall limit myself to the finding, that this US debate focuses on the highly contested view whether corporate boards should aim at maximising shareholder value ${ }^{84}$ or have discretionary power or even legal duties to allocate corporate assets to the benefit of other stakeholders. Not only much later, after World War II,but conceptually more important also quite different from the US CSR debate has been the development of the notion CSR in Europe. On our continent CSR relates to business and society in general, regardless of the legal form in which the business operations are conducted. See for instance the Dutch acronym MVO or Maatschappelijk Verantwoord Ondernemen, in which the legal form does not figure at all. The emphasis is on the way business is actually conducted by any entrepreneur, whether a single operator, a partnership or a company, so not exclusively on the responsibilities of

\footnotetext{
82 De Hoo 2011, p. 15. See also Dommerholt 2009, Melé 2008, p. 49-55 and Orlitzky 2008, p.113-134.

83 Cf Van Oosterhout \& Heugens 2008, who point to the importance of the need to link the operationalization of CSR and the theoretical definitions of CSR (p. 204).

84 Friedman 1970.
} 
a corporation as a legal entity towards society. Although the latter is an important issue per se as we shall see later, it unduly narrows the focus of CSR in the context of my observations.

When we consider the different CSR theories, it is important to keep this conceptual distinction of "business" as an activity versus "corporation" as a legal entity in mind. In a very concise and highly instructive article Prof. Domenec Melé of IESI Business School in Barcelona classified the different CSR approaches and philosophies under the following four main headings:

- Corporate Social Performance, a theory grounded in sociology;

- Shareholder Value Theory or Fiduciary Capitalism, a particular economic theory;

- Stakeholder Theory, which in its normative version is based on ethical perspectives ${ }^{85}$ and,

- Corporate Citizenship, rooted on political studies. ${ }^{86}$

As you will see there is no legal approach or philosophy mentioned or included, although the last three categories relate to certain aspects of the primary legal form in which business is conducted, the corporation. Only the first theory, Corporate Social Performance or CSP, is conceptually legal form neutral. I quote Melé: "In order to determine specific responsibilities, many authors insist on the importance of paying attention to social expectations regarding the firm's performance and concern for social needs. Among other arguments for assuming CSR, it is stressed that business has power and power requires responsibility. It is also emphasized that society gives business licence to operate and, consequently, business must serve society not only by creating wealth, but also by contributing to social needs and satisfying social expectations towards business." 87

\footnotetext{
85 The term stakeholder was introduced by Freeman in 1984 (Freeman 1984); Donaldson and Preston 1995 distinguish three modes of stakeholder theory: descriptive, instrumental and, lastly, normative. They note that a shift from a shareholder to a stakeholder model requires a normative justification and point to Freeman and Evan's recommendation that a Rawlsian "veil of ignorance" will be applied in order to render the stakeholder bargains "fair". See for this reasoning Crane, Matten \& Spence 2008, p. 154-155

86 Melé 2008.

87 Melé 2008, p. 49.
} 
5.4 CSR through the legal lens, corporate citizenship and the licence to operate

How then should we look at CSR through a legal lens? As lawyers being quite familiar with this concept I submit that the best starting point for our endeavour is the concept of the licence to operate, in this case the metaphoric licence extended by society to business within the realm of the latter's corporate citizenship, another metaphor familiar to lawyers. Like ordinary citizens corporations are bestowed by society with citizen rights, albeit with the limitations necessarily following from their status as legal persons, but as the rights of natural citizens come with responsibilities ${ }^{88}$, likewise the rights of corporate citizens are conditioned by responsibilities. These responsibilities are not necessarily legal responsibilities as we have seen in the case of Ruggie's corporate responsibility to respect human rights. Rousseau's social contract theory, as revived by John Rawls ${ }^{89}$ and by Amartya Sen90, may serve as the political-philosophical basis of corporate citizenship. ${ }^{91}$ The idea of the corporate social contract was developed by Business Ethics scholar Thomas Donaldson: business receives from society a number of privileges, mainly in conjunction with the institutionalised legal personality, such as limited liability for shareholders and managers, in exchange for which society receives certain benefits from business. Society agrees to this exchange as long as these benefits exceed the costs for society. ${ }^{92}$ The idea of a global social contract including the business sector is also the basis for the Earth Charter, a code developed by influential world leaders and prominent political and philosophic thinkers in the nineties aimed at a model for, in my words, Triple $P$ inclusive global governance. It is based on a tripartite understanding of governments, business and civil society. ${ }^{93}$ As a corollary of the corporate social contract, business is granted by society its licence to operate. This licence consists of several sublicences. Best known to us as lawyers is of course the legal licence to operate, extended pursuant to law by competent authorities, to engage

\footnotetext{
88 Hirsch Ballin 2011.

89 The political theory based corporate citizenship conception reflecting the licence to operate reminds us of the social contract theories, which in Rawls' modern version is built in the presumption of justice as fairness.

90 Sen 2009, p. 361-364 on human rights.

91 See for a well-elaborated outline of the theory of corporate citizenship R. Jeurissen 2002, Interestingly, in academic literature there is also mention of corporate citizenship as conceptually equivalent yet rhetorically superior synonym of CSP (Orlitzky 2008, p 116). In my vision as laid out in this lecture corporate citizenship is the political philosophical basis for the normative concept of CSR while CSP is the corollary to CSR for its practical implementation

92 Donaldson 1982. See also de Hoo 2011, p. 11, referring to the principle of reciprocity, also a corporate social contracts based approach.

93 Lubbers, van Genugten \& Lambooy 2008.
} 
in certain business activities or perform certain business functions subject to legal conditions, monitored and enforced by the courts of law and/or other legally competent authorities. As we have seen, however, in view of the development and significance of alternative forms of regulation (often referred to as mechanisms "in the shadow of the law") it will be more appropriate to refer nowadays to the regulatory licence to operate. Next to this regulatory sublicense, however, traditionally there is an important second sublicense, the social licence to operate. This is the domain of those legitimate expectations of society that have not (yet) crystallized into law or any other manner of regulation. Monitoring and enforcement of this licence is entrusted to the courts of public opinion, whether or not called to attention by activist NGO's, and, as we have seen for instance in the case of Shell's plans to sink the Brent Spar in the Atlantic, these courts, called to duty in this case by Greenpeace, can be highly effective. Companies that have experienced enforcement by the courts of public opinion know their powers. Quite often do they extend in reach and effect considerably beyond the powers of the legal courts.94 Gunningham, writing on Corporate Environmental Responsibility95, eloquently explains why in his opinion the licence to operate concept captures the complexity of the relationship between the regulated enterprise and key stakeholders well. He provides three perspectives.

First, the concept of a licence encapsulates the extent to which various stakeholders can bestow or withdraw privileges from a company in a direct relationship. Second, the relationship between companies and the stakeholders is an interactive one with many of the terms open to negotiation with the possible effect that the social licence, voluntarily or imposed, will crystallize into one of the forms of regulatory licence. Third, the notion of an overall licence encompasses Gunningham's empirical observation that there is indeed considerable interaction among its components, the regulatory and the social licence, to which he adds a third sublicense, the economic licence. ${ }^{96}$ I shall leave this latter for the moment. Gunningham mentions also a fourth sublicense, the collective licence to operate. Systematically, this is

94 As e.g. Shell and Walmart have experienced boycotts by the customers of their poducts as reactions to their policies (environmental in the case of Shell's intended disposal of the Brent Spar and Walmart in the case of alleged discrimination in employment practices). These boycotts were sparked by NGO actions.

95 Gunningham 2007.

96 This latter licence reminds us of Archie Carroll's pyramid of corporate responsibilities, the first and basic one of which is the economic responsibility: a reasonable rate of return as foundation upon which all other responsibilities, the legal responsibility, the social responsibility and the discretionary or philanthropic responsibility rest. I shall revert to this when we shall deal with the future of corporate law. See also de Hoo 2011, p. 21 
a variance of the individual social sublicense extended to a whole industry by society to the sector concerned based on certain collective self-regulation measures adopted by that sector. The extractive industry and the chemical industry are cases in point: both industries have developed important self-regulatory instruments based on societal pressure, such as the Extractive Industry Transparency Initiative to disclose the payments by the industry to governments or the Responsible Care program of the Chemical Industry, adopted in the aftermath of the Bhopal disaster in 1984.

My intention was to show, how the mainly academic normative and the practical operational notions of CSR could be reconciled. The linked concepts of corporate citizenship and licence to operate on the one hand and the corporate social performance concept on the other hand nicely bridge the divide. 


\section{Reinforcing the licence to operate by changing the paradigms in company law}

\subsection{CSR and regulation, form following function}

Having analysed the phenomenon of CSR through a legal lens, I must now address the main task I have set myself to deliver on the promise by colleague Sybren de Hoo, namely to provide you with thoughts about regulatory options to reinforce the licence to operate, which, as he concluded, is badly needed. 97 And, as I have already mentioned, he is in the good company of such influential thought leaders as Cadbury, Reich, Stiglitz, Lord Wedderburn and many others as I already mentioned or will do in this lecture.

A closer look at the CSR debate shows interesting and important legal questions indeed. Which substantive norms in the Triple P scope need regulatory intervention and, if so, what type of regulation? Can it be left to business to regulate itself or is soft law or even hard law needed to protect the interests of society or individuals? Should transparency of operations be arranged on the basis of mandatory reporting? And how should universal fundamental norms be protected, now that the nation state is still the prevailing authority to shape and enforce law, but at the same time multinational companies are organized and active in many jurisdictions without a global government system 9 $^{8}$ How does CSR impact on corporate decision-making and what rights do the various stakeholders in companies have to influence or challenge corporate decisions? What is the role of business in the field of human rights: to protect or to respect and how do these concepts differ? What responsibility does business have to assure that human rights are respected in their supply chains?99 What remedies are available in case business is not living up to societal expectations or to legal obligations impacting on the rights or interests of third parties? Are parent companies responsible and liable for the actions of their subsidiaries abroad and on what substantive law basis, that of the home country or the host country?

97 de Hoo 2011, Par 5

98 Stiglitz 2006.

99 The Draft UN Norms 2003 recommended that business was equally responsible for the realisation and protection for human rights as states are. As I have set out earlier this recommendation was not adopted by the UN Human Rights Committee (now UN Human Rights Council) and it recommended the appointment of a special representative of the UN Secretary General on the issue of business and human rights. Prof John Ruggie was appointed and the rest is history: states have the duty to protect and business has the corporate responsibility to respect. See also Kinley,Nolan \& Zerial 2007 and Eijsbouts 2009. 
The story of the regulatory travels of the substantive anti-bribery norm has already provided us with a wide range of options of regulatory mechanisms including hard law in all forms, administrative policies and decisions, soft law, and self-regulation, in collective or individual form. Together with the CSR substantive norms, which are uncodified or unwritten, these norms crystallized in any one or more of these regulatory forms are the constituent parts of the licence to operate granted by society to business as we have seen earlier. I note, by the way, that self-regulation in its collective or individual forms is often the result of public government pressure in the form of threatened regulation, if no action is taken by business itself. ${ }^{100}$

With respect to the objectives of all these forms of regulation, the first distinction to be made from a CSR point of view is that between:

(a) those laws and forms of regulation (individual and collective self-regulation included) which encourage or stipulate the right business conduct;

(b) those laws and regulations (or possibly also contractual arrangements) which provide remedies for third parties harmed by improper business conduct, and

(c) those laws and forms of regulation, which impose administrative fines or criminal sanctions on violations of the CSR laws and regulations.

You will remember the concentric circles I showed you earlier. Category (c) is by definition hard law or based on hard law. Category (b) is mainly public tort law, unless contracts made in the supply chain provide stipulations for the benefit of third parties, who are entitled under the relevant contractual provisions to a direct cause of action (jus quaesitum tertio, derdenbeding). Although adequate remedies in case of harm are certainly important and pose difficult legal questions in case the harm occurs abroad, directly or through subsidiary companies, from the perspective of the desired outcomes, decent and responsible business conduct is our primary goal. Therefore, I shall concentrate on category (a) and leave categories (b) and (c) aside, at least for the moment.

The next preliminary observation is that regulation can either be Triple $P$ sector specific, such as the laws preventing water, air or soil pollution in the Planet sector, or cover a range of CSR topics, such as the OECD 
Guidelines or the UN Global Compact, or be of a general nature like corporate, contract, tort or criminal law.

The most pertinent example of the latter category is corporate law, which regulates the management and supervision of corporations, including the reporting on its activities. Through the application of CSR substantive norms in the interpretation of open or blanket norms relating to the way management and supervision should conduct the business in a responsible way, CSR norms may become legally relevant for the company and possibly also for its directors and officers collectively or individually. The relevant cultural orientation (shareholder or stakeholder focused) and the legal architecture of the particular national company law system (for listed companies accompanied by securities laws and regulation) as the central regulatory complex within a wider corporate governance context will answer the question of, whether and to what extent specific CSR norms will be taken into account by the courts, if the management and supervision policies, decisions and practices are challenged. Legal concepts such as fiduciary duties, duties of care, good faith, adequate management, gross or simple mismanagement are all possible entrances for CSR norms to play a role in the courts' judgments. ${ }^{101}$ The Dutch company law system provides, in addition, for a so far unique system for relevant stakeholders to request an order by the Enterprise Chamber for an official inquiry by experts into the management practices. If the findings will lead to the assessment by the court of actual mismanagement, the court has far reaching powers to intervene. These include even such drastic measures as the annulment of management decisions, the appointment of interim managing and/or supervisory directors and amendment of the articles of association. Colleague Bas Steins Bisschop deserves praise as the first legal scholar in the Netherlands to have explored already in 2000 in his inaugural lecture at Nyenrode University the possible relation between CSR and company law.

Since this is also the main research field of our Institute of Corporate Law, Governance and Innovation Policies, launched today, I shall concentrate on the company law and governance regulation of corporations, in view of our Globalisation focus with a particular lens on multinational

101 For an analysis of the possible interaction of CSR-norms and Dutch corporate law, see Steins Bisschop 2004 and Eijsbouts 2010. We are divided on the question whether CSR as such is a relevant legal notion, which is argued by Steins Bisschop. I take the view that the container nature of CSR, being a collection of pluriform substantive norms, cannot serve as such as a relevant legal notion similarly as the notion corporate governance which also contains many norms and like CSR in many forms. 
corporations and address three themes: the nature of the corporation as such, the nature of corporate groups and, finally, the liability of corporate groups in CSR cases. ${ }^{102}$ But allow me to provide you first with some introductory comments.

6.2 Players, rules and tools; an anatomic lesson

In order to show the players of the game, its rules and the tools to be deployed by each of them, I developed in 2004 the following schematic overview of its legal anatomy, which has proven quite useful: ${ }^{103}$

\section{Corporate Governance and CSR}

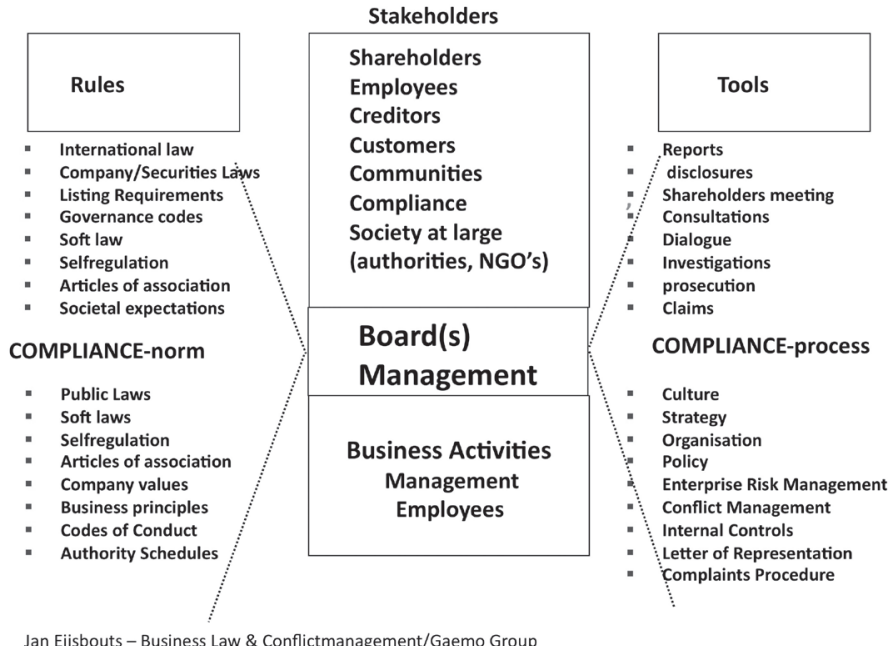

Jan Eijsbouts - Business Law \& Conflictmanagement/Gaemo Group

At first sight this scheme looks more complex than it is in reality. You see three vertical columns: the players in the middle, the rules on the left and the tools on the right. Management and supervision of course take the pivotal position in the game. From their perspective there is an internal management and organisational dimension, which you will find on the lower half of the scheme with the business managers and the employees, and an accountability or external dimension on the upper half with the stakeholders. Both dimensions have of course their specific set of rules in accordance with the rights and obligations

\footnotetext{
102 I note that most substantive CSR norms and forms of CSR regulation address also businesses conducted either in a non-incorporated way or in a different type of legal form, but this type of regulation is mostly Triple P-sector oriented and therefore covers many types of business activities, discussion of which goes considerably beyond the scope of my lecture.

103 One of my outside counsels advised me even to obtain copyright, but it remains freely available!
} 
of the players in those dimensions. On the rules side you will see the smart regulatory mix of norms. The traditional governance regulatory mix is located on the upper half of the left column and the CSR or Triple $\mathrm{P}$ regulatory mix which governs the actual business operations is mainly located on the lower half of the left column. Relations with personnel, possible impact on third party human rights, environmental and fair play regulations, such as competition laws and anti-bribery laws and accounting rules, are to be found in this lower part of the left column. Increasingly important, both in corporate governance and a CSR context, are the tools for adequate management in the lower half of the right column. The right strategy with a sustainable business model comes first, complemented with a values based culture, followed by the right organisation and policies including risk and conflict management and internal monitoring and controls. In the upper half of the right column you will find the regular and ad hoc communication patterns for transparency, accountability and dialogue with shareholders and other relevant stakeholders. Also intervention possibilities for shareholders and other stakeholders to question and, if necessary, challenge management policies and decisions in court and for authorities to investigate and possibly prosecute the company and/or its directors and officers are to be found here.

\subsection{Corporate governance and CSR intertwined}

Having sketched for you the playing field for the various players in the corporate governance and CSR field, I now turn to the relation between both these frameworks. This is a theme with progressing insight. The classical view was that both have different dimensions. Corporate governance merely related to the primary players in the corporate field: management, supervision and shareholders, while CSR had an external focus: stakeholders and wider society. ${ }^{104}$ Their interdependence became however quickly clear and the more progressive view, as also voiced by colleague Sybren de Hoo in his lecture ${ }^{105}$, is that corporate governance is next to the three P's the fourth substantive subject of CSR. ${ }^{106}$ Walsh and Lowry also share the vision that CSR encompasses corporate governance:

"...Corporate governance is an increasingly important aspect of CSR. And, as they continue to develop, corporate governance principles will

104 Slagter 2005, p. 135 and Lambooy 2010, chapter 2.

105 de Hoo 2011, following Dommerholt 2009.

106 Following Dommerholt he even added it as a fourth CSR driver to the Triple P. My submission would be that governance in this sense belongs to the process rather than to the substantive aspect of CSR. 
continue to provide the more solid foundations on which broader CSR principles - and business ethics - can be further enhanced."107

The most recent view, however, is that the corporate governance concept, of course in an extended way, should encompass CSR. The number of scholars representing this view is steadily increasing. There are ample arguments to support this view. These are partly of an empirical, partly of a descriptive and partly of a normative nature. Empirical support comes from the drafters of the US Sarbanes Oxley Act 2001, the response to the corporate scandals at Enron, Tyco and WorldCom, which mandated the SEC to adopt stronger corporate governance requirements for listed companies. Following this mandate the SEC instructed the US Stock Exchanges to require listed companies to adopt, monitor and enforce a code of conduct, typically encompassing the usual CSR topics. ${ }^{108}$ The motives were of course protection of the company's reputation and thereby securing shareholder value. The sanction was drastic, as could be expected from the US securities regulator: delisting! Additional empirical support can be found in the OECD Corporate Governance Principles 2004, which in their introductory remarks characterized the remit of corporate governance as:

"Maximising value subject to meeting the corporation's financial, legal and other obligations. This inclusive definition stresses the need for board of directors to balance the interests of shareholders with those of other stakeholders - employees, customers, suppliers, investors, communities - in order to achieve long term sustained value."

The Dutch Corporate Governance Code 2009, the revised version of its predecessor 2004 Code which already provided for the need to establish a code of conduct, adopted CSR in principle II.1. as one of the core responsibilities of management. Management is accountable on this new task to the Supervisory Board and the General Meeting of Shareholders. In the tradition of the European corporate governance codes the "comply or explain" rule applies, but according to the drafters of the Dutch Code, this rule only applies to the Code's best practices, not to its principles. ${ }^{109}$ That being so, I submit it would have been anyway an impossible task for management to explain, that it would not accept this new responsibility.

107 Walsh \& Lowry 2005, in Mullerat 2005, p. 38.

108 See the corporate governane requirements of NYSE and Nasdaq

109 De Monchy \& Legein 2009. 
As I said, many authoritative scholars and business leaders represent this latest view on the extended scope of corporate governance. ${ }^{110}$ Among them not least Sir Adrian Cadbury, European Corporate Governance patriarch, chairman of the UK Committee to draft the first national Corporate Governance Code in Europe and inventor of the "comply or explain" formula, who wrote in 2000 :

"Corporate governance is concerned with holding the balance between economic and social goals and between individual and communal goals. The governance framework is there to encourage the efficient use of resources and equally to require accountability for the stewardship of those resources. The aim is to align as nearly as possible the interests of individuals, corporations and society."111

It could be argued that these comments are not necessarily relevant, since corporate governance is formally only directed to listed companies. There is, however, a counter argument: many non-listed companies and organisations, including those not for profit, have embraced the corporate governance principles to the extent applicable. It was therefore not surprising, that the EU in its 2011 green paper on corporate governance ${ }^{112}$ requested views on whether or not corporate governance should be made formally applicable also to non-listed companies.

The reason why I have expanded on the inclusion of CSR in corporate governance is the fact, that corporate governance since its introduction in the early nineties of the last century is becoming the most important integral normative framework for the management and supervision of listed, and increasingly also non-listed companies. As we have seen the regulatory anatomy of corporate governance is similar to that of CSR, but there is an additional reason for this proposition. As recent issues have shown, quite a few problems in corporate land are both governance and CSR related. I mention the increasingly uneasiness of investors and the general public about executive pay. In the still highly relevant 1976 RIO

110 Eg Clarke 2007, chapter 8, Kerr, Landa \& Pitts 2009, p. 21. See also Zumbansen 2009. Bob Tricker provides a brief history of the evolution of corporate governance,: "The original corporate governance codes, dating from the early 1990 s, were voluntary. At the time they were derided by some company chairmen as being no more that expensive, box ticking exercises. But since then three significant changes have taken place. Firstly, corporate governance compliance has increasingly become mandatory, enshrined in regulation or in some cases law. Complaints now tend to be about the cost of compliance not about the need of corporate governance codes. Secondly, risk analysis and risk management have become an integral part of the coprorate governance process. Thirdly and most recently, corporate social responsibility and sustainability have been added to the corporate goverance portfolio." Tricker 2009, p. 349,

111 A. Cadbury, foreword in World Bank, Corporate Governance, a Framework for Implementation, Washington 2000, cited in Clarke 2007.

112 EUROPEAN COMMISSION, GREEN PAPER, The EU corporate governance framework Brussels, 5.4.2011 COM (2011) 164 final. 
report ${ }^{113}$ to the Club of Rome, prepared under the coordination of Nobel laureate Jan Tinbergen, the income relation found between the rich and the poor was 13:1. Tinbergen would like to decrease this within 40 years to 3:1. What we see nowadays, however, 35 years later, is that the relation in income between the US CEO and the average (not even lowest, sic) US employee often is much more than 13:1. In 2009 the latter relationship was 263:1. ${ }^{114}$ This would seem unsustainable and this problem is both governance as well as CSR related. In the US this has caused the introduction of so-called "say on pay" rules, by which shareholders can influence or even control executive pay.

As already mentioned the well-known governance problems at ENRON, Tyco, Worldcom, Ahold and Parmalat in the beginning of the last decade prompted intensified corporate governance regulation, but it is clear, that many of the problems could have been labelled as CSR problems as well. Trust, with the primary and secondary stakeholders, is a central notion in both corporate goverenance and CSR.

\subsection{Smart regulatory policies: nudge, meta-regulation, and transparency}

What is smart government policy in this regard? The first comment to be made is that law and regulation have their limitations and are certainly not always the best way to regulate behaviour. ${ }^{115}$ Wellknown Chicago Professors Richard Thaler and Cas Sunstein developed their libertarian-paternalistic policy of Nudge ${ }^{116}$, soft pushes by government or regulators, but unnoticed as such by the public, into the direction of the decisions by the public that the government deems best for the public. These nudges should be realised by a smart choice architecture. There are simple examples such as placing the products in a certain way in the supermarket in order to let the customers making healthier choices, but there are also rather complicated examples, e.g. in the Planet-field the very successful emission trading system for the control of acid deposition ('acid rain'), introduced as an amendment in 1990 to the US Clean Air Act. As compared with a command-and-control system, the traditional way of governmental regulation, the trading mechanism is estimated to have saved $\$ 357$ million annually in its first five years. ${ }^{117}$

113 RIO stands for Reshaping the International Order; the The RIO Report was prepared for the Club of Rome in 1976 by a committee formed and coordinated at the request of Dr Aurelio Pecci, the Chaiman of the Club's Executive Committee, by Prof Jan Tinbergen. The report was issued in book form by Elesvier Amsterdam in 1976 and contains the reports by subcommittees of international experts in their field.

114 Research by US Institute for Policy Studies, referenced in De Volkskrant, 1 September 2011.

115 E.g. Munneke 2008, Westerman \& Mackor 2008, Raaijmakers 2005.

116 Thaler \& Sunstein 2009

117 Thaler \& Sunstein 2009, 199. 
Although certainly not unimportant, ample doubt is justified whether merely pursuing this policy in the regulation of business would restore the confidence of the public in the system.

The government pressure can take the form of making government assistance conditional upon the voluntary adoption of non-binding instruments or codes. Ruggie's smart mix includes for instance the suggestion to only grant export credits or export insurance if the beneficiary has pledged to live up to the OECD guidelines, which in their updated 2011 version include the corporate responsibility to respect human rights in a new chapter specifically drafted for this purpose. Ruggie's extension of the corporate responsibility to the supply chain adds the use of contract law to the mix, the so-called "contractualization of human rights". ${ }^{118}$ So by the adoption of Ruggie's Framework by the OECD in its 2011 version of the Guidelines for Multinationals, Ruggie's non-legal universal baseline expectation has become soft law, and this with a hardening effect in the form of a more strict National Contact Point (NCP) procedure to deal with complaints of non-compliance with the Guidelines. An example, where the UK NCP used Ruggie's due diligence approach in the supply chain even before the update of the Guidelines, was the Afrimex case. ${ }^{119}$ This could point to a future acceptance of Ruggie's Framework as international customary law.

In connection with CSR and smart regulation another legislative technique should be mentioned, that of so-called meta-regulation. ${ }^{120}$ The concept of meta-regulation reflects the idea, that it is possible to regulate behaviour without doing so directly. ${ }^{121}$ It implies that direct intervention and enforcement are replaced with "allegedly lighter demands on economic actors to institutionalize processes of selfregulation". ${ }^{122}$ Meta-regulation strategies in this sense are contingent on the relevant substantive area of regulation; for instance, in the context of the regulation of competition, meta-regulation might mean governmental monitoring of organizations own competition compliance programmes. ${ }^{123}$ An example of this type of regulation are the US Federal Organizational Sentencing Guidelines ${ }^{124}$, which provide for norms for courts and prosecutors to sanction violations by companies of criminal

118 McBarnet \& Kurkchyan 2007.

119 See for an interesting analysis of the semi-legal nature of the OECD NCP-procedure Catá Backer 2009.

120 Parker 2007.

121 Bomhoff \& Meuwese 2011, p. 141

122 Jordana \& Levi-Faur 2004, 6-7, quoted by Bomhoff \& Meuwese 2011, p. 141.

123 Bomhoff \& Meuwese 2011, p 141-142.

124 The US Federal Sentencing Guidelines, Compliance Program Requirements

http://Www.ussc.gov/Guidelines/2010_guidelines/Manual_HTML/8b2_1.htm. 
laws, such as the antitrust laws and the anti-bribery laws. Effective compliance programs, of which the main features are described in the Guidelines, are taken into account positively in the imposition of fines and jail sentences. These guidelines, therefore, are an example of inducement of companies to adequate self-regulation in the fields of substantive legislation. ${ }^{125}$ Or as Parker clarifies: "Law attempts to constitute corporate "consciences" - getting companies to want to do what they should do - not just legally compliant outputs or actions... Meta-regulation - the proliferation of different forms of regulation (whether tools of state law or non-law mechanisms) each regulating one another - is a key feature of contemporary governance".126 Parker argues, "that it is possible, in principle at least, to imagine (and even to see partial examples) of meta-regulation that holds business organisations accountable for putting in place corporate conscience processes that are aimed at substantive social values".127 In the field of self-regulatory corporate governance codes, the legal basis to "apply or explain, that and why they don't comply" with the code designated by the legislator could be regarded as meta-regulation. Parker suggests that, in order for laws to successfully meta-regulate CSR, they must:

(1) be aimed at making sure that companies meet "values that transcend narrow self-interest";

(2) be aimed at making sure that these values are built into the practice and the structure of the enterprise; and

(3) recognise that the main goals of the organisation are still to be pursued within the responsibility framework. ${ }^{128}$

It goes beyond the scope of this lecture to further delve into this important aspect of CSR regulation and in particular compliance, but it will certainly be a topic for further analysis in the future. That research cannot be performed in splendid legal isolation. Although corporations may have a conscience, in practice decisions compliant with responsibilities are human actions. Interestingly, also in the context of "regulating CSR", the report on the EU conference, which I mentioned earlier, does not address the concept of CSR from a legal or regulatory point of view and follows the traditional EU voluntary approach for CSR. The report, however, notes, that while "analysis had revealed that the forms of CSR preferred by companies were

125 I note, that the EU Commission or the EU Courts so far have not been prepared to use this type of metaregulation in the fight against EU competition law violations.

126 Parker 2007, p. 208.

127 Parker 2007, p. 209.

128 Parker 2007, p. 215-217. 
unilaterally imposed codes of practice and ethics charters, a process could be observed whereby over time CSR becomes "legalised" through the creation of legal and paralegal instruments". The conference report, however, also refers to the conclusion of one of the research teams, "that responsibility is fundamentally an individual issue and needs to be studied as such. There is a need for research that focuses on internal learning and change processes. This requires detailed research over time, including inputs from psychology and neuroscience, as well as sociology and organisational theory, in order to gain an understanding of what goes on in peoples' minds when they make decisions". 129 It shows how complex the issue of responsibility is and that the role of meta-regulation may become an important topic for crossdisciplinary research. Law should not be left out of this research as the work by Tom Tyler on legal compliance shows: his fascinating book is entitled "Why people obey the law" without a question mark.130

Before going into the thick of corporate law and address the three themes I would like to explore, I should mention the disciplinary effect of transparency and business reporting, my third concentric circle. Sybren de Hoo mentioned the ambitious GRI Guidelines for integrated reporting on financials and so-called non-financials, the latter of which include the Triple $P$ domains. ${ }^{131}$ Denmark was the first country to require extended non-financial reporting systems for its bigger companies. ${ }^{132}$ Companies that already use the GRI-framework are exempt from this requirement. The EU Commission is expected to come out later in this year with its report on its 2010 consultation on mandatory CSR-reporting 133 , following the rather non-committal EU Modernisation Directive of 2003. ${ }^{134}$

\subsection{Company law, changing paradigms in the shadow of CSR}

\subsubsection{Constitutional foundation; the company's interest as pluralist concept}

The first of my three themes on company law goes to the heart of the corporation, its constitutional foundation. ${ }^{135}$ There are three main schools of thought. Originally a corporation was a concession

129 See also Heugens, Kaptein and van Oosterhout 2007 on the relation between responsibility and organisation.

130 Tyler 2006.

131 de Hoo 2011, p. 43, see also Raaijmakers 2005 on the limited prospect of discipline by transparency.

132 Denmark: Danish Financial Statements Act, which came into force on January 1, 2009

133 EU Public consultation on disclosure of non-financial information by companies, 23.11.2010 - 24.01.2011

134 Kamp-Roelands \& van der Zanden 2005, Lambooy 2010, chapter 4, Eijsbouts 2010, par 4.

135 Kerr, Janda \& Pitts 2009, chapter 3. 
or licence granted by the government whether or not based on an act of parliament to a number of natural persons who had requested the concession to raise capital for a defined purpose and specifically approved with the privilege of limited liability for the incorporators. The justification of this limited liability was to be found in the public interest, which the corporation would serve. Although elements of this original characteristic of the corporation can still be traced in certain jurisdictions ${ }^{136}$, over the centuries the concession aspect disappeared and today, if there still is a concession aspect involved ${ }^{137}$, it is not linked to any specified and defined public interest, unless of course the corporation's aims and objects are precisely geared to a defined public function. ${ }^{138}$ As the public purpose and the requirement of a concession disappeared and corporations started to grow and raise capital on regulated stock exchanges to expand their business, by which the ownership became dispersed, the relation between management and these owners received close attention. As agents or trustees for the owners, who had decreasing control over them, managers were able to serve their own interest at the expense of the owners. This contractual agency relationship therefore became the central point of focus in the conceptual approach of corporations. Hence the emphasis on the notion that corporations would be merely a legal fiction and in fact no more than a nexus of contracts. The pivotal one of these contracts was the agency contract between the owners and the managers, hence the name agency or contractual theory. This concept also implies that the shareholders not only own the company but also its assets, which are entrusted to the managers based on their so-called fiduciary duty. This concept is also referred to as the shareholder model in corporate law, since the corporation is basically indentified with its shareholders. Agency theory has long prevailed in Anglo-American corporate law systems and traces can still be found. The modern view of the corporation, however, is based on the concept that it is a legal institution in its own right, owning its assets and being responsible for its liabilities. This is the constitutional concept of the corporation which is characterized by a multitude of constituencies, management, shareholders, creditors, employees, suppliers and customers, local

136 Such as the requirement of government approval for incorporation, recently abolished in the Netherlands.

137 E.g. consisting of the requirement of governmental approval for incorporation and the articles of association.

138 Note, that for these cases specific conditions have been formulated by law or even specific forms of incorporation have been developed. De Jongh, Schild and Timmerman 2010 and 2011. 
communities and authorities, hence the name stakeholder model. Stephen Bottomley's summary of the constitutionalist theory encapsulates the elements from the three visions:

"The theory of corporate constitution begins with the proposition that corporations are more than just artificially created legal institutions (contrary to the suggestion of contrary to the suggestion of concession theory) and they are more than just economic institutions (contrary to the argument of contract-based theories). Corporations have both these dimensions, but they are also social enterprises and they are polities in their own right." 139

My proposal is that the constitutional vision of the company with its pluralist approach, reflected in the notion "the interest of the company" (het vennootschappelijk belang) which has been one of the principles of Dutch ${ }^{140}$ and other continental-European jurisdictions, and which has been adopted in the Dutch Corporate Governance Code, will be reflected in the Dutch Companies' Act. ${ }^{141}$ Not in a structural sense as happened in 1971, when labour was given the right to co-determine the composition of the Dutch supervisory board of the big companies, but in the specification of the duty of care of management. ${ }^{142}$ The proposal is to adopt the duty of care guidelines for UK directors, as reflected in section 172 of the UK Companies Act 2006, in our Dutch Civil Code in order to clarify the current undefined and much debated notion "the company's interest" in art. 2:140.2 Dutch Civil Code. ${ }^{143}$ Section 172 UK Companies Act stipulates, that UK- Directors must promote the success of the company for the benefit of its members and in doing so have regard to various factors, e.g.

- the likely consequences of any decision in the long term;

- the interests of employees;

- the need to foster the company's relationships with; suppliers, customers and others;

139 S. Bottomley, "The Birds, the Beasts and the Bat: Developing a Constitutionalist Theory of Corporate Regulation" (1999), 27 Fed. L.Rev. 243 at 255, cited in Kerr, Landa \&Pitts 2009; see also the report on Ruggie's Corporate Law Project on the possibilities to reflect the need for corporations to respect human rights in company and securities laws (Ruggie 2010)

140 Eijsbouts 2010, par 5.2, Eijsbouts 2011.

141 Eijsbouts 2010, par. 8.2.

142 See Timmerman 2009, who signals the trend to no longer provide stakeholder influence through measures in the structure of companies, but to arrange for adequate attention to stakeholders' interest through more specified and targeted duties of care of management. See on the latter also Raaijmakers 2005, Tjong Tjin Tai 2007, Heineman 2008, de Waard 2008, Steins Bisschop 2008 and Assink 2007 and 2009.

143 See Eijsbouts 2010 for a concise review of the various visions and interpretations of the nature and the content of the notion "company's interest", see also Assink 2010 and, for the role of the company's interest in hostile takeover procedures, Steins Bisschop 2008 and van Ginneken 2010. 
- the impact of operations on the community and the environment;

- the desirability of the company maintaining a reputation for high standards of business conduct.

This new UK approach is called the "enlightened shareholder value" model. ${ }^{144} \mathrm{~A}$ real pluralist approach is not (yet) achieved since other than the shareholders, interested stakeholders have not been given the possibility to enforce this duty in court against allegedly negligent directors. Therefore, my proposal would be to grant those stakeholders, acknowledged or to have been acknowledged as such by the company pursuant to principle II.1 of the Corporate Governance Code and (threatened to be) affected by structural negligence by management of its duty to take their interests into account, a conditional right of action. It would entail the possibility of an official inquiry into possible mismanagement ordered by the Enterprise Chamber. To avoid abuse of this right, interested stakeholders should file their request with the Advocate General at the Amsterdam Court of Appeal, who shall scrutinize the request and if found sufficiently substantiated by him or her, file the official request on their behalf with the Enterprise Chamber. It would be extension of the AG's right to request an official inquiry in the public interest. ${ }^{145}$

I have raised this idea before ${ }^{146}$, but to no avail. ${ }^{147}$ I am convinced, however, that the current debate on the conceptual foundations of the corporate form justifies an indepth study. The idea for such a radical departure from the traditional shareholder model in company law is in line with many suggestions from CSR proponents ${ }^{148}$ and even mentioned in the recent EU Corporate Governance Green book ${ }^{149}$ questionnaire as a topic for consideration. The EU Green Paper on Corporate Governance and the Report of the EU Reflection Group are examples of the concerns, which have been raised by the developments leading to the financial, economic and public debt crisis and the roles of business in modern society. It would also nicely tie in with Ruggie's Corporate Law project, which aimed at possibilities to use company law as a means to make company boards more accountable for their corporate responsibility to respect human rights. ${ }^{150}$ Finally, the recent report of the EU Reflection

\footnotetext{
144 Davies 2005, Horrigan 2011, part 3, point 7, Timmerman 2009 and de Kluiver 2009, Calkoen 2011, par 2.6.3

145 Boukema 1969, Schmieman 2004, Eijsbouts 2010, par. 8.3, Mok 2004.

146 Eijsbouts 2010.

147 Handelingen NJV 2010-2, question 2.

148 Horrigan 2011, chapter 10; Porter \& Kramer 2011, Sjåfjell 2009 and 2011 and de Hoo \& Olaerts 2011.

149 EU EUROPEAN COMMISSION GREEN PAPER The EU corporate governance framework, Brussels, 5.4.201, $\operatorname{COM}(2011) 164$ final.

150 Ruggie 2010, analysis of 40 major jurisdictions by 19 major international law firms.
} 
Group suggests to offer companies the possibility to adopt a more stakeholder oriented approach in their policies and practices. ${ }^{151}$

\subsubsection{Corporate groups; aligning law with economic reality}

Let me now turn to my second major revision proposal in company law. This relates to the possibility to align corporate group law with economic and organisational reality. Current corporate group law is still centred on the individual company concept with all its requisites. ${ }^{152}$ These include limited liability for the shareholders and managing directors, the duty for the latter to take into account the interest of the individual company (depending on the relevant jurisdiction of the subsidiary company reflecting either a shareholder or a stakeholder model), different regimes for capitalisation and creditor protection. In some jurisdictions the possibility exists of holding the shareholders liable via an "internally routed" piercing the corporate veil process or via "externally routed" legal concepts, such as principal-agency concepts or identification (vereenzelviging) of legal entities. ${ }^{153}$

There are three main reasons for a fundamental review of this model, based on the individual legal entity. ${ }^{154}$ The first one is the frequently occurring incongruity between the primordial organisational structure of the group and its legal structure. 155 Organisational lines of command frequently cross or skip one or more individual legal entity borders for a variety of reasons (such as historic reasons or the establishment of national holdings for tax or financial consolidation). In order to structure the internal organisational lines of command the group establishes, next to its business mission statement, vision and values principles, such instruments as codes of conduct and detailed approval and authority schedules as well as detailed reporting models, again all based primarily on organisational structure rather than legal structure. Business managers, who frequently do not have a legal position in the group companies, which are involved in their business decisions, rely on the Legal Department for the necessary corporate housekeeping to secure that their business decisions and actions are reconciled with the formal legal requirements. The second reason is a corporate governance reason. Most prevailing corporate governance regimes

\footnotetext{
EU Reflection Group on Company Law 2011.

2 Lennarts 1999, Raaijmakers 2009, EU Reflection Group on company law 2011, Chapter 4.

153 Lennarts 2002, Timmerman 2002, Vandekerckhove 2007, Bartman \& Dorrestein 2009.

154 EU Reflexion Group 2011, Chapter 4.

155 Van den Ingh 2002, Lennarts 2002, Muchlinski 2007, van der Sangen 2009
} 
require extensive risk management and control systems. ${ }^{156}$ In order to implement these control requirements detailed reporting and monitoring systems have been developed which enable the group parent company's managing directors to follow the operations of the business groups and legal entities closely. These developments have raised the idea of constitutionalization of multinationals. Multinationals have their own internal governance structures that have to be in line with the various external legal regimes and national and international codes governing the group operations worldwide on the one hand and their complex internal structures on the other hand. Ideas to come to grasp with these possibly conflicting frameworks, securing at the same time legitimacy also towards the outside world(s), have been formulated. Teubner has been the creative inventor of this concept. Others followed suit. 157 An interesting topic in this area is privacy protection, another CSR and human rights concern. In order to reconcile the cross border privacy data communication needs of multinationals on the one hand and the manifold differing national and supranational regimes in this field on the other hand, the concept of so-called "binding corporate rules" (BCR) was developed. The data protection authorities assembled in the so-called Art 29 Working Party ${ }^{158}$ embarked on a model to endorse rules in this respect that may assist the multinationals in bad need of harmonisation in this area. ${ }^{159}$ The binding corporate rules regime provides for a specific internal data protection governance and security system, which will allow the free cross border flow of data within the multinational group, subject to the many data protection regimes applicable to the group. ${ }^{160}$ I mention in particular the requirements that the $B C R$ should incorporate the material data processing principles (transparency, fairness, purpose limitation, data quality, rights of individuals and security) and restrictions on onward transfers (rule $v$ ) and that the BCR should be internally binding within the organisation (on all group companies and on emloyees) and externally binding for the benefit of individuals (i.e. must create third-party beneficiary rights for individuals (rule vi). ${ }^{161}$

156 Schoordijk 2005 and Strik 2009; see also Eijsbouts 2010, par 7.3. Cf also the US Sarbanes Oxley Act S. 404 , on the internal control systems primarily aimed at integrity of the financial accounting system and the resulting financials in periodic reports.

157 Teubner 2009a, Lambooy 2011, who envisions the future development of a Multinational Companies Constitution and provides a possible framework with procedural elements.

158 The Working Party 29 is an advisory body for the EU Commission established under article 29 of the EU Data Protection Directive. See for the international governance framework of data protection rules in general and the workings of the binding corporate rules. Moerel 2011.

159 Moerel 2011, par. 6.1 under the telling title "data here, data there, data everywhere", p 179

160 Moerel 2011, par. 10.2, p. 272-276.

161 Moerel 2011, p. 274 and 275. 
The third reason is that regulators or courts disregard the legal structure and give precedence to the organisational lines of command in their approach of corporate groups. This happens frequently in competition law enforcement procedures both in the administrative and criminal aspects $^{162}$ as well as in the civil damages context.

For these reasons my proposal would be to look again at the suggestion by Slagter in $1988^{163}$ to consider the possibility of a legal entity status for the corporate group as such, of course next to the different legal entities which compose the group. It would be a challenging project, as Slagter's discussion with Raaijmakers has shown ${ }^{164}$, but my assumption is that it is worthwhile considering, particularly with a view to avoid the need of cutting the Gordian knot in cases where organisational responsibilities and legal responsibilities cannot be reconciled or the latter are even impossible to identify. Of course the important developments in governance systems and the protection of minority shareholders and creditors of group subsidiaries need careful attention.

\subsubsection{Multinational enterprise liability; fundamental rights and global remedies}

My final major revision proposal relates to the remedy of corporate violations of fundamental rights of third parties by legal entities within legal groups. This proposal is a corollary from the first and second proposals and is aimed a trying and establishing a multinational enterprise liability system for these violations. ${ }^{165}$ - The concept of multinational enterprise liability was first developed in the context of the Bhopal disaster in $1984 .{ }^{166}$ These revision aspects of the proposal are the establishment of global substantive liability norms and the review of

61 Moerel 2011, p. 274 and 275.

162 ECJ Akzo Nobel NV and Others v Commission (C-97/08 P), Olaerts \& Cauffmann 2011.

163 Slagter 1988, Blumberg 1993, Eijsbouts 2010.

164 Raaijmakers 1990, Slagter 1990, Timmerman 2002, Muchlinski 2007 and Eijsbouts 2010.

165 Hofstetter 1990, who analyses from the "law and sociology" as well as "law and economics"

perspectives the principle of legal independence of group subsidiaries operating in so-called host countries. Hofstetter clarfies that the principle of International Social Efficieny (ISE), which has helped in formulating the concept of "optimal tariffs" in the area of international trade, could in the same vein be expected to lend itself toward the development of optimal MNE liability regimes in the area of international direct investment. ISE is used by Hofstetter along the "Kaldor-Hicks" concept of efficiency, i.e. a rule is efficient if its gains to some actors exceed its losses to others. The compensation of the losers by the winners is not dealt with by Hofstetter, but is nevertheless assumed by him to happen (note 30 to his article). This assumption needs careful CSR scrutiny.

166 Van Rooij 1990.

167 In this respect I deviate from the proponents of so-called foreign direct liability (FDL), and its most expansive form being the litigation on the basis of the US Alien Torts Statute of 1789, which should give foreign plaintiffs access to US courts in cases against foreign corporations. See Castermans \& van der Weide 2009, Augusteinm 2010, Enneking e.a. 2011. See for my reasons to deviate from FDL Eijsbouts 2010, par. 8.4, and Handelingen NJV 2010-2, question 3. See also Zerk 2006, p. 240 who concurs in my views on FDL and Stiglitz 2006 on global norms and a global court. 
cases by a supranational forum, such as the WTO. ${ }^{167}$ The WTO often tries cases involving the claims by multinationals as investors, but the WTO should be taking also cases against multinationals who are not living up to their responsibilities in the host country. ${ }^{68}$ The idea is that the management board of the parent company is supposed to be in control of those operations of the subsidiaries of the group that may affect the fundamental rights of third parties. And this is for two reasons: infringing those rights may lead to high risks for the company, but it may also lead to high risks for the third party rights holders. ${ }^{169}$ Cases in point are Shell in Nigeria and BP in the Gulf of Mexico. It is Ruggie's philosophy to see his due diligence system work both ways, that is preventing legal and reputational risks for the company as well as preventing possible damage to third parties by the operations of the company. ${ }^{170}$ This is a novel departure from the traditional approach to due diligence, which was primarily concerned with the protection of the position of the company itself. ${ }^{171}$ Of course harming third parties may also be a risk factor for the company itself172, but the angle to look particularly to the position of the third parties, regardless of whether there is risk of damage for the company itself, is new.

An additional aspect of my proposal would be to reverse the burden of proof for the third party. Again, for the same reasons as mentioned above in the second proposal, when I spoke of the difficulty to identify exactly the right person or legal entity not only to have been involved in but also to have violated the relevant duty of care, this reversal of the burden of proof would be realistic. It would be compatible with the in control rules and mechanisms of the multinational on the one hand and with the practically impossible situation of the damaged party to find out and prove the relevant facts in the case on the other hand. As I said already, ideally, these cases should in my opinion neither be tried in court in the home state of the multinational nor in the host state against the multinational. In both cases the court could be prejudiced against the foreign party in the case. In addition, the level playing field sought by this proposal would not be realised. ${ }^{173}$

\footnotetext{
168 Burianski 2007.

169 See van Genugten \& Jägers 2003 on the binding effect of human rights on corporations.

170 See Schweisfurth 2011 for an indepth analysis of the responses by mutinationals to the allegations of human rights abuses by them, as published by THE BUSINESS \& HUMAN RIGHTS RESOURCE CENTRE (http://www.business-humanrights.org/Aboutus/Briefdescription).

171 Brink 2011

172 See Ruggie 2008, point 4, p 6, see also point 51, p 14-16, where Ruggie provides a list of human rights relevant for business, drawn from over 300 reports of alleged corporate-related human rights abuses; see also Ward 2003 and Zerk 2006
} 


\section{From Practice to Theory, Epilogue}

As mentioned in the introduction, little could I imagine in 2005 that the writing of an article would result in my appointment at this University in this very elegant and enjoyable city, which now includes the neighbouring village of Heer in which I was born, but, hopefully more interesting to you, would result in this inaugural lecture. I would now like to address also in particular our students.

My aim has been not only to provide a critical note to the still prevailing view that CSR is voluntary and to provide hopefully convincing arguments that law and regulation are important for CSR, but also to demonstrate that CSR is a fascinating theme for law students and to propose possible new avenues for corporate law. Once voluntarism has been unmasked as non-essential characteristic of CSR, wide panoramas open up for lawyers. The "trade mark" of our university, problem based learning, is well served by the multifaceted topic CSR, since, as I have illustrated, it covers many fields of legal theory and practice, nationally, internationally and, increasingly important, also transnationally. We have crossed many borders: those between law and non-law, between national law and international law both public and private, between international law and transnational law, between public and private national law, between public regulation and private regulation, between law and economics, between law and sociology, between law and politics, between law and justice, between law and morals and, finally, between law and ethics, both in theory and in practice. CSR covers all of these territories, regardless of whether it is characterized by those who deem it fit for their purposes as being limited to the "beyond the law" territory. It puts the law as traditional and still primary method of regulation of the relationship between business and society in the context of a quickly emerging international and transnational pluralistic regulatory landscape. It offers today's students, our tomorrow's lawyers, a kaleidoscopic view on tomorrow's role of law and regulation in business as an increasingly influential player in the governance of an ever more complex and globalising society. ${ }^{174}$ The master theses which I have supervised this past year show, how this CSR topic has sparked interest with our students in diverse national, transnational and international legal

173 van Dam 2008, p. 51.

174 See the Hiil Law of the future project, which offers a fascinating look at the prospects of the development of law in three possible scenarios for the coming 20 years ( $w w w$. Lawofthefuture.org) and the collection of think pieces which have contributed to the conception of these scenarios. These think pieces are assembled in Muller e.a. 2011, which is also available on line (FICHL Publication Series No. 11; Publication Series The Law of the Future and the Future of Law - FICHL (www.fichl.org/fileadmin/fichl/documents/FICHL_11_Web.pdf). 
aspects, ranging from the hardening effect in the soft law based OECD guidelines for MNC's 2011, via the contractualisation of human rights in the clothing industry's supply chain implementing Ruggie's Guidelines 2011 and the CSR transparency in disclosure regulation in the US vs. that in The Netherlands, to the whistle blowing provisions of the Dodd Frank Act in the US in comparison with the whistle blowing provisions in German Labour law, particularly in the field of anti-bribery legislation. It has been a stimulating experience and with colleague Sybren de Hoo I am looking forward to the coming years and to the inspiring contacts and conversations with our many international students, by which also my international outlook on the world's development continues to be guaranteed. The positive criticism we received on this first year's course will be taken on board to further improve the course, the topic of which as such already received a high grade.

Next to education I am looking forward to participate, with the ICGI team, in those research topics which are geared to improving governance, including CSR, and corporate law as its core to enhance the role of the integral governance framework in supporting corporate policies which improve sustainable business. The proposals I have made this afternoon in this connection will of course belong to my research agenda. 


\section{Acknowledgements}

Ladies and gentlemen, acknowledgements are owed to many people at the end of my inaugural lecture ${ }^{175}$ and a very long afternoon. So first of all, I like to thank you all for coming to our launching event. Then, I would like to thank those, who have contributed to my legal education, starting at Groningen University in 1964, and my practical experience during my 36-year tenure as corporate counsel in fine companies with great colleagues. I mention one of them in particular: Professor Cor Uniken Venema, my inspiring teacher of Anglo American Law in Groningen and later dedicated tutor in my first job at Philips, who enthused me to become an international corporate counsel and convinced me to abandon the idea to start as an advocaat, at least until 2001, when I joined the bar as Cohen Advocaat.

Outside the legal field I had the privilege to work with many great and inspiring colleagues, but I specifically mention my two CEO's at Akzo Nobel, Kees van Lede and Hans Wijers, under whose leadership I was entrusted with the task to manage the legal teams in all major transactions from 1993 onwards, which transformed the hybrid Akzo group, which I joined in 1989, to the focused AkzoNobel, which I left in 2007. But perhaps more importantly, they supported me throughout in my endeavours to further the right legal and, together with my colleague Andre Veneman, ethical compliance culture at the company, which brought a great and valuable experience also for my current capacity.

This brings me to Professor Menno Kamminga's call, end of November 2009, with his straightforward question: how about becoming a professor of CSR in Maastricht? One month later Dean Professor Aalt-Willem Heringa and Menno convinced me, that this totally unexpected switch to academia was the right choice to combine a long international legal experience in practice with an increasing interest in the nature and workings of law and regulation in society. Menno and Aalt-Willem, I owe you both a great debt of gratitude for your endeavours to support my appointment by the Board of the Stichting Wetenschapsbeoefening UM in this capacity. Menno, you deserve additional thanks for your continuing guidance in my induction program. It became, however, very soon clear to me,

175 I am grateful to the following persons in particular for taking the trouble to read an earlier draft of this lecture and to offer their valuable comments and suggestions: Jim Brumm, who was kind enough to also screen the draft on English, Tom Eijsbouts, Sybren de Hoo, Kid Schwarz and Birgit Spiesshofer. 
that my colleagues Professors Kid Schwarz and Bas Steins Bisschop had been the actual drivers of my appointment and, Kid and Bas, that knowledge increased my appetite even more. My debt is certainly owed to you as well!

Having worked now for a year at the Institute whose launch is getting to its end in a couple of minutes, I must also thank my other direct colleagues at ICGI, in particular Christine van Basten, Mieke Olaerts, Jos Hamers and Yvonne Walhof for their dedicated and highly valued support in my initiation, both scientifically and organisationally, in this new world.

Finally in Maastricht, my collega proximus, Professor Sybren de Hoo: Syb, it has been a great pleasure, right from our first meeting and dinner, working together on the creation of the curriculum for and the teaching in our CSR course in the master Globalisation and Law. Coming from very different corporate corners, but valuing the potential of our complementary fields of experience, we have taken on the challenge of creating, with our excellent leaders of our tutorial groups Anna Beckers and Valentina Vadi, an inspiring CSR course for law students from many different nationalities and legal study orientation. I look forward to continue working with you in the coming years with the same good spirits to offer our students hopefully challenging and relevant education for their future contribution to a better world.

Last but by no means least I must address my direct personal stakeholders, my family. Roderick and Charlotte, partners Anna and Sebas, and grandsons Renzo and Klaas: we are teaching our students, that stakeholder engagement is of crucial importance. If my international corporate counsel career and subsequent professional challenges did not always allow me bringing this theory in practice fully, I pray for your understanding and look forward to be the engaged father and grandfather you all deserve. It goes without saying, however, that my primary engagement focus will be my better self, Gabriella: you have been supporting me tremendously over all those years, even if I tested your patience unduly and took on too many additional burdens. My pledge is, that this lecture was the last one of those.

Ik heb gezegd. 


\section{Literature}

Assink 2007

B.F. Assink, Rechterlijke toetsing van bestuurlijk gedrag (dissertatie Rotterdam), Uitgave Instituut voor Ondernemingsrecht, Deventer: Kluwer 2007.

Assink 2009

B.F. Assink, Deel I - Facetten van verantwoordelijkheid in hedendaags ondernemingsbestuur, in: Ondernemingsbestuur en risicobeheersing op de drempel van een nieuw decennium: een ondernemingsrechtelijke analyse, Preadvies van de Vereeniging 'Handelsrecht' 2009, Deventer: Kluwer 2009.

Assink 2010

B.F. Assink, De Januskop van het ondernemingsrecht, over faciliering en regulering van ondernemerschap (oratie Rotterdam),

Deventer: Kluwer 2010.

Augenstein 2010

Augenstein e.a., Study of the Legal Framework on Human rights and the Environment Applicable to European Enterprises Operating outside the European Union, submitted by the University of Edinburgh, Study for the European Commission ENTR/og/o45 (2010).

Barkhuysen \& van Emmerik 2010

T. barkhuysen en M.L. van Emmerik, Ongebonden binding, Verwijzing naar soft law-standaarden in uitspraken van het EHRM, NTM/NJCM-Bull. Jrg. 35 [2010], nr 7-60 jaar EVRM, p. 827-835.

Bartman/Dorresteijn 2009

S.M. Bartman en A.F.M. Dorresteijn, Van het concern, zevende druk, Deventer: Kluwer 2009.

Blowfield-Murray 2011

Michael Blowfield and Mark Murray, Corporate Responsibility, Oxford University Press, second edition 2011. 
Blumberg 1993

Philip Blumberg, 'The Multinational Challenge to Corporation law: The Search for a new Corporate Personality', Oxford: Oxford University Press, 1993.

Bomhoff \& Meuwese 2011

J. Bomhoff and A. Meuwese, The Meta-regulation of Transnational Private Regulation, in Journall of Law and Society, Vol 38, number 1, March 2011, p 138-162.

Boukema 1969

C.A. Boukema, 'Algemeen belang en ondernemingsbelang', in Op de grenzen van komend recht, opstellen aangeboden aan Prof. Mr J.H. Beekhuis, Zwolle: Tjeenk Willink en Deventer: Kluwer 1969.

Brink 2011

M. Brink, Due diligence, een beschouwing over het due diligence onderzoek naar het Nederlandse recht, dissertatie Maastricht, 2008, ze druk, Den Haag: Boom 2011.

Burgmans 2008

Rapport van de Commissie Burgmans over de verhouding MVO en corporate governance, uitgebracht op 6 november 2008 aan de Staatssecretaris van Economische Zaken (www.ez.nl).

Burianski 2007

M.Burianski, Is there a role for the WTO in the Conflict between Globalisation and the Protection of Social Norms?, in K. Byttebier \& K. Van der Borcht (eds). WTO Obligations and Opportunities, Challenges of Implementation, London: Cmeron May, p. 427-442.

Cafaggi 2011

F. Cafaggi, New Foundations of Transnational Private Regulation, Journall of Law and Society, Vol 38, number 1, March 2011, p 20-49.

Calkoen 2011

W.J.L. Calkoen, the One-Tier Board in the changing and converging world of corporate governance, dissertation Rotterdam, 2011.

Calliess \& Zumbansen 2010

G-P Calliess and P. Zumbansen, Rough Consensus and Running Code, A Theory of Transnational Private Law, Oxford: Hart Publishing 2010. 
Carroll \& Shabama 2010

Carroll, Business and Society: Ethics and Stakeholder Management, Cincinnati: South Western College Publishing, 1996, nr 74.

Carroll \& Shabama 2010

A.B. Carroll and K.M. Shabana, The Business Case for Corporate Social responsibility: A review of Concepts, Research and Practice, in International Journal of Management Reviews 2010, p. 85-105.

Casey \& Scott 2011

D.Casey and C. Scott, "The Crystallization of Regulatory Norms" in The Challenge of Transnational Private Regulation, conceptual and constitutional debates, Journal of Law and Society, Vol 38, number 1, March 2011, p. 76-95.

Castermans \&Van der Weide 2009

A.G. Castermans en J van der Weide, De Juridische verantwoordelijkheid van Nederlandse moederbedrijven voor de betrokkenheid van dochters bij schendingen van fundamentele, internationaal erkende rechten, Leiden, 15 december 2009 www.ez.nl.

Cat. Backer 2009

L. Cat. Backer, Rights and Accountability in Development (Raid) V Das Air and Global Witness V Afrimex: Small Steps Toward an Autonomous Transnational Legal System for the Regulation of Multinational Corporations, Melbourne Journal of International Law, Vol. 10.

(Available at SSRN).

Clarke 2007

Thomas Clarke 'International Corporate Governance, a Comparative Approach', London and New York: Routledge 2007.

Code Banken 2009

Nederlandse Vereniging van Banken, De Code Banken 2009 www.nvb.nl.

Crane, Matten \& Spence 2008

A. Crane, D. Matten and L. Spence (ed), Corporate Social Responsibility, Readings and cases in a Global Context, 2008, Abingdon, Routledge. 
Van Dam 2008

C.C. Van Dam, Onderneming en mensenrechten, oratie Utrecht 2008, Den Haag: Boom 2008.

Davies 2005

P. Davies, Enlightened Shareholder Value and the New Responsibilities, W.E. Hearn Lecture at the University of Melbourne Law School, 4 October $2005\langle w w w . c c l s r . l a w . u n i m e l b . e d u . a u\rangle$.

Dommerholt 2009

Dommerholt, E., Corporate Sustainability Performance: constructs, measures and investors' responses, Thesis, Vrije Universiteit Amsterdam, Amsterdam, The Netherlands, 2009.

Donaldson 1982

T. Donaldson, Corporations and morality, Prentice Hall, Englewod Cliffs, New Jersey, USA.

Donaldson \& Dunfee 1999

T. Donaldson and T. Dunfee, Ties that Bind, A Social Contracts Approach to Businss Ethics, Boston, MA: Harvard Business School Press 1999.

Donaldson \& Preston 1995

T. Donaldson and L. Preston, The stakeholder theory of the corporation: Concepts, Evidence and Implications, 20 The academy of Management Review 65.

Dworkin 2006

R. Dworkin, Justice in Robes, The Belknap Press of Harvard University Press, Cambridge MA, 2006.

Eijsbouts 2005

A.J.A.J. Eijsbouts, 'CSR, a matter of principle(s), law or both?' in S.H.A. Dumoulin ea (red.), Tussen Themis en Mercurius, Bedrijfsjuridische bijdragen aan een Europese beleidsconcurrentie, Lustrumuitgave Nederlands Genootschap van Bedrijfsjuristen, Deventer: Kluwer 2005, p. $83-96$ 
Eijsbouts 2009

A.J.A.J. Eijsbouts, 'Ruggie's law: filling the human rights' governance gap for multinationals in public international law', in: Met Recht, opstellen over privaat- en ondernemingsrechtelijk ondernemingsrecht, aangeboden aan Theo Raaijmakers, Deventer: Kluwer, 2009, pag. 89-97.

Eijsbouts e.a. 2010

A.J.A.J. Eijsbouts, F.G.H. Kristen, J.M. de Jongh, A.J.P. Schild \& L.Timmerman, 'Maatschappelijk verantwoord ondernemen, naast in of met recht' in: Maatschappelijk verantwoord ondernemen (Handelingen Nederlandse Juristen-Vereniging 2010-I), Deventer: Kluwer 2010.

Eijsbouts 2010

A.J.A.J. Eijsbouts, Algemene beginselen van maatschappelijk verantwoord ondernemen (Handelingen Nederlandse Juristen-Vereniging 2010-I), Deventer: Kluwer 2010.

Eijsbouts 2011

A.J.A.J. Eijsbouts, International Market Regulation, Corporate Governance, CSR and Multinationals, in Muller e.a., The Law of the Future and the Future of Law, HiiL, FICHL Publication Series No. 11 (2011).

Enneking 2009

L.F.H. Enneking, 'Crossing the Atlantic? The Political and Legal Feasibility of European Foreign Direct Liability Cases', The George Washington International Law Review 2009, vol. 40, p. 903-938.

Enneking e.a. 2011

L. Enneking, I. Giesen, M.J.van der Heijden, T. Lambooy, M.L. Lennarts en J.Visser, Privaatrechtelijke handhaving in reactie op mensenrechteschendingen door international opererende ondernemingen, in NTM/NJCM-Bull. Jrg. 36 [2011], hr 5, p. 541-560.

EU Commission 2001

Commission of the European Communities, Green Paper: Promoting a European framework for Corporate Social Responsibility, COM (2001) 366 final, Brussels, 18-7-2001. 
EU Company Law Reflexion Group 2011

Report of the Reflection Group On the Future of EU Company Law Brussels, 5 April 2011.

Van Eyk 1995

S.C. van Eyk, The OECD Declaration and decisions concerning Multinational Enterprises, dissertatie RUU 1995, Ars Aequi Libri 1995.

Friedman 1970

M. Friedman, 'A Friedman Doctrine - The Social Responsibility of Business is to Increase its Profits', The New York Times Magazine (September 13, 1970). p. 17.

\section{Giesen 2007}

I. Giesen, 'Alternatieve regelgeving in privaatrechtelijke verhoudingen', in: NJV Preadviezen Alternatieve regelgeving 2007, Deventer: Kluwer 2007, p. 67-168.

Van Ginneken 2010

M.J. van Ginneken, Vijandige overnames. Een rechtsvergelijkende studie naar de rol van de vennootschapsleiding in Nederland en de Verenigde Staten, Dissertatie UvA, 2010.

Glinski 2007

C. Glinski, Corporate codes of conduct: moral or legal obligation?

P. 119-147, in The new corporate accountability, Cambridge University Press: 2007 .

Van Genugten \& Jägers 2003

W.J.M. van Genugten en N.M.C.P. Jägers, 'Juridische gebondenheid van ondernemingen aan de rechten van de mens', in: W.J.M. van Genugten en C. Flinterman (red.), Niet-statelijke actoren en de rechten van de mens; gevestigde waarden, nieuwe wegen, Den Haag: Boom 2003.

\section{Gunninham 2007}

N. Gunningham, Corporate environmental responsibility: law and the limits of voluntarism, in McBarnet, Voiculescu and Campbell 2007, p 476-500. 
Hamers, Schwarz \& Steins Bisschop 2005

J.J.A. Hamers, C.A. Schwarz en B.T.M. Steins Bisschop 'Maatschappelijk Verantwoord Ondernemen: juridisering van een relatief vaag normenkader', in 'Noodzaak, plicht of wenselijkheid van Maatschappelijk Verantwoord Ondernemen', een multidisciplinaire verkenning' Den Haag: Boom, 2005, p. 1-11.

Handelingen NJV 2010-2

Handelingen Nederlandse Juristen Vereniging , 140e jaargang/2010-2, Maatschappelijk verantword ondernemen, verslag van de op 11 juni 2010 te Amsterdam gehouden alegemene vergadering, Kluwer Deventer 2011.

Hart 1961

H.L.A. Hart, The Concept of Law, second edition 1994, Oxord University Press, 199.

Heineman 2008

B. Heineman, High Performance with High Integrity, Boston, USA: Harvard Business Press, 2008.

Heugens, Kaptein \& van Oosterhout 2007

P.M.A.R. Heugens, M. Kaptein and J. van Oosterhout, Contracts to Comminities: a Processual Model of Organizational Virtue, ERIM Report Series Research in Management, ERS-2007-023-ORG, (www.erim.eyr.nl).

Van den Heuvel 2009

A. Van den Heuvel, Labor rights as Human Rights vs Multinational Corporations: responsibility and accountability, Kennispunt Faculteit Recht, Economie, Bestuur en Organisatie, Universiteit Utrecht 2009.

Hirsch Ballin 2011

E. M.H. Hirsch Ballin, Burgerrechten, Inaugural Lecture University of Amsterdam, 2011.

Holmes 1897

O.W. Holmes, 'Natural Law'. In: Harvard Law Review, vol. 10, nr. 1 (1897): blz. 40-44. 
Hofstetter 1990: K. Hofstetter, 'Multinational Enterprise Parent Liability: Efficient Legal Regimes in a World Market Environment', 15 NCJ Int'I \& Com. Reg 299 (1990).

De Hoo 2011

S.C. de Hoo, In pursuit of corporate sustainability and responsibility: past cracking perceptions and creating codes. Inaugural Lecture Maastricht University, 2011.

De Hoo e.a. 2010

Hoo, S.C. de, Groot, L.C.M., Jonge, F.H., Dommerholt, E. and Bunders, G.F., Duurzaam ondernemen: een onderzoek naar effectieve stimulering, verbreding en verankering, Vrije Universiteit, Amsterdam, Nederland, 2010.

De Hoo \& Olaerts 2011

S.C. de Hoo \& M. Olaerts, Sustainable development and the need for sustainable oriented corporate law and regulation, to be published in SSRI.

Horrigan 2011

B. Horrigan, Corporate Social Responsibility in the 21st Century, Cheltenham UK - Northampton, MA US: Edward Elgar, 2011.

Hoskins 2008

Tony Hoskins, The ICSA 'Corporate Social Responsibility Handbook', London: ICSA Information and Training Ltd 2008.

IBA 2008

Report of the IBA Legal Practice Division Task Force on Extraterritorial Jurisdiction, London: International Bar Association 2008.

Van den Ingh 2002

F.J.P. van den Ingh 'De bevelsstructuur in de vennootschap' in Concernverhoudingen', in: Concernverhoudingen, Serie vanwege het Van der Heijden Instituut, Deventer: Kluwer 2002, p. 13-27.

Jessup 1956

Ph. Jessup, Transnational Law, Storrs Lectures in Jurisprudence at Yale Law School, Yale University Press, New Haven CT, 1956. 
De Jongh, Schild \& Timmerman 2010

M. de Jongh, A. Schild en L.Timmerman, Naar Maatscahppelijke varianten van de rchtsvormen in Boek 2 BW, in Maatschappelijk verantwoord ondernemen (Handelingen Nederlandse Juristen-Vereniging 2010-I), Deventer: Kluwer 2010.

De Jongh, Schild \& Timmerman 2011

M. de Jongh, A. Schild en L. Timmerman HiiL, The Rise of the Social Enterprise: How Social Enterprises Are Changing Company Law Worldwide, in Muller e.a., The Law of the Future and the Future of Law, HiiL, FICHL Publication Series No. 11 (2011).

Jeurissen 2002

R. Jeurissen, De Onderneming als wereldburger, Inaugural Lecture at Nyenrode University, Nyenrode University Press 2002.

Kamp-Roelands \& Van der Zanden 2005

A.E.M. Kamp-Roelands en P.M. van der Zanden 'Maatschappelijk Verantwoord Ondernemen en maatschappelijke verslaggeving' in Hamers, Schwarz \& Steins Bisschop 2005, p. 169-192.

Kerr, Janda \& Pitts 2009

M. Kerr, R. Janda en Ch.Pitts (eds) 'Corporate Social Responsibility, a legal analysis', LexisNexis, Canada 2009.

Kinley, Nolan \& Zerial 2007

David Kinley, Justine Nolan and Natalie Zerial, The Norms are dead, long live the Norms! The politics behind the UN Human rights Norms for corporations, in McBarnet, Voiculescu and Campbell 2007, P 459-475.

De Kluiver 2009

H.J. de Kluiver, 'Vennootschappelijke repliek op Timmerman's grondslagen', Ondernemingsrecht 2009-4.

Kristen 2004

F.G.H. Kristen, Misbruik van voorwetenschap naar Europees recht, Dissertation Tilburg, Nijmegen: Wolf Legal Publishers 2004. 
Kristen 2010

F.G.H. Kristen, 'Maatschappelijk verantwoord ondernemen en strafrecht', in: Maatschappelijk verantwoord ondernemen (Handelingen Nederlandse Juristen-Vereniging 2010-I), Deventer: Kluwer 2010.

\section{Lambooy 2010}

T.E. Lambooy, Corporate Social Reponsibility, Legal and semi-legal frameworks supporting CSR, diss Leiden 2010, IVO nr 77, Deventer: Kluwer 2010.

Lambooy 2011

T.E. Lambooy, Corporate Law and CSR,: Will there be a Constitution for multinational Companies in 2030, in Muller e.a., The Law of the Future and the Future of Law, HiiL, FICHL Publication Series No. 11 (2011).

Lambooy, Raic \& Kryczka 2009

T.E. Lambooy, D. Raic, K. Kryczka: Concept Paper: Globalization, The Nation State and Private Actors, rethinking Public-Private cooperation in shaping Law and Governance, HIIL Law of the Future Conference, Den Haag 2009.

Lebano 2010

A. Lebano, The concept of corporate social responsibility, a philosophical approach, ISS Working paper no 508 <http://repub.eur.nl/resource/ pub_21243/index.html>.

Lennarts 1999

M.L. Lennarts, Concernaansprakelijkheid (diss. Groningen), IVO, Deventer: Kluwer 1999.

Lennarts 2002

M.L. Lennarts 'Wat weet een concern(vennootschap)' in Concernverhoudingen, Serie vanwege het van der Heijden Instituut, Deventer: Kluwer 2002, p. 57-70.

Lokin 2008

J.H.A. Lokin, De ontoereikendheid van een codificatie, in Westerman \& Mackor 2008, hoofdstuk 1, p. 15-31. 
Lubbers, van Genugten \& Lambooij 2008

R. Lubbers, W. van Genugten en T. Lambooy, 'Inspiration for Global Governance. The Universal Declaration of Human Rights and the Earth Charter', Kluwer 2008.

Makinwa 2011

Abiola O Makinwa, 'Future Thinking' through the Prism of International Corruption, Award winning Essay at Hiil Law of the Future Conference, 23-24 June, 2011.

McBarnet, Voiculescu and Campbell 2007

D. McBarnet, A. Voiculescu and T. Campbell (ed.), The New Corporate Accountability, Corporate Social Responsibility and the Law, Cambridge University Press, Cambridge 2007.

McBarnet \& Kurkchyan 2007

D. McBarnet and M. Kurkchyan, Corporate social responsibility through contractual control? Global supply chains and 'other-regulation', in McBarnet, Voiculescu and Campbell 2007, p 59-92.

Melé 2008

D. Melé, Corporate Social Responsibility Theories, p. A. Crane et al (ed.) The Oxford handbook of Corporate Social Responsibility, Oxford University Press 2008, 47-82.

Moerel 2011

E.M.L. Moerel, Binding Corporate Rules, fixing the regulatory patchwork of data protection, Dissertation Tilburg, Amsterdam 2011, ISBN.

Mok 2004

M.R. Mok, 'Het recht van enquête onderzocht', in: Preadvies Vereeniging Handelsrecht 2004 door M.W. Josephus Jitta en M.R. Mok, Deventer: Kluwer 2004, p. 45-9.

De Monchy \& Legein 2009

C.W. de Monchy en M.H. Legein (eindred.) 'Corporate Governance in Nederland', ze druk, Den Haag: Boom 2009.

Muchlinski 2007

P.T. Muchlinski, Multinational Enterprises \& The Law, Second edition, Oxford: Oxford University Press 2007. 
Muller e.a 2011

S. Muller, S. Zouridis, M. frishman and L. Kistemaker (editors), The Law of the Future and the Future of Law, HiiL, FICHL Publication Series No. 11 (2011).

Mullerat 2005

Ramon Mullerat (Ed.), Corporate Social Responsibility, the corporate governance of the 21st century, The Hague: IBA \& Kluwer Law International 2005.

Munneke 2008

S.A.J. Munneke, Sterven niet toegestaan, over de mogelijkheden en onmogelijkheden van goede wetgeving in Westerman \& Mackor 2008, hoofdstuk 2, p. 33-50.

Nederlandse Corporate Governance Code 2003: De Nederlandse Corporate Governance Code, Commissie Corporate Governance (Cie Tabaksblat), 9 december 2003 (wWw.commissiecorporategovernance.nl).

Nederlandse Corporate Governance Code 2009: De Nederlandse Corporate Governance Code, Commissie Corporate Governance (Cie Frijns), 10 december 2008. 〈WWW.commissiecorporategovernance.nl $\rangle$.

Nijman 2005

J.E. Nijman, Corporate Social Responsibility, a conceptual challenge to international law? In Noodzaak, plicht of wenselijkheid van Maatschappelijk Ondernemen, by J.J.A. Hamers, C.A. Schwarz and B.T.M. Steins Bisschop (editors), Boom Juridische Uitgevers, Den Haag, 2005.

OECD Guidelines 2011

OECD Guidelines for Multinational Enterprises 2011, available at: <http:// webnet.oecd.org/oecdacts/Instruments/ShowlnstrumentView.aspx?Ins trumentID=233\&InstrumentPID=271\&Lang=en\&Book=False $>$.

Olaerts \& Cauffmann 2011

M. Olaerts and C.Cauffman, Qu"mica: Further Developing the Rules on Parent Company Liability, to be published. 
Van Oosterhout \& Heugens 2008

J. van Oosterhout and P. Heugens, Much ado about nothing: a conceptual critique of Corporate Social Responsibility, in A. Crane et al (ed.) The Oxford handbook of Corporate Social Responsibility, Oxford University Press 2008, p. 197-223.

Orlitzky 2008

M. Orlitzky, Corporate Social Performance and Financial Performance, in A. Crane et al (ed.) The Oxford handbook of Corporate Social Responsibility, Oxford University Press 2008, p. 113-134.

Parker 2007

C. Parker, Meta-regulation: legal accountability for corporate social responsibility, in McBarnet, Voiculescu \& Campbell 2007, p. 207-240.

Porter \& Kramer 2011

Michael E. Porter and Mark Kramer: "Creating shared value. How to reinvent capitalism - and unleash a wave of innovation and growth", Harvard Business Review, January-February, 2011.

\section{Raaijmakers 1990}

M.J.G.C. Raaijmakers, 'Dient een concern te worden beschouwd als rechtspersoon',TVVS 1990, $\mathrm{nr}$ 90/2.

Raaijmakers 2005

G.T.M.J. Raaijmakers, De Effectiviteit van regels in het ondernemings- en effectenrecht (oratie Maastricht), Den Haag: Boom 2005.

Raaijmakers 2009

M.J.G.C. Raaijmakers, Naar een Wetboek Ondernemingsrecht? (Afscheidscollege Universiteit van Tilburg), 27 november 2009.

Rees 2008:

Caroline Rees, Rights-compatible Grievance Mechanisms: A Guidance Tool for Companies and their Stakeholders, Corporate Social Responsibility Initiative, Working Paper No 41, John F. Kennedy School of Government, Harvard University, 2008.

Reich 2009

R. Reich, Supercapitalism, The Battle for Democracy in an Age of Big Business, UK Edition, Icon Books Ltd, London 2009, p. 168-169. 
Reinhardt 2008

F.Reinhardt, R.N. Stavins, R.H. Vietor, Corporate Social Responsibility through an Economic Lens, Corporate Social Responsibility Initiative, Working Paper No 43, John F. Kennedy School of Government, Harvard University, 2008.

Rogmans 2007

B.G.P Rogmans, Verkeersopvattingen, Monografie"n BW, Deventer: Kluwer 2007.

Van Rooij 1990

R. van Rooij, 'De moeder, de dochter, het concern en de calamiteit' in: Aansprakelijkheden, lustrumbundel Nederlands Genootschap van Bedrijfsjuristen, Deventer: Kluwer, 1990, pp 177-195.

Ruggie 2007

The Special Representative of the Secretary-General, Report of the Special Representative of the Secretary-General of the United Nations on Human Rights and Transnational Corporations and Other Business Enterprises: Business and Human Rights: Mapping International Standards of Responsibility and Accountability for Corporate Acts, A/ $\mathrm{HRC} / 4 / 35,19$ February 2007.

\section{Ruggie 2008}

The Special Representative of the Secretary-General, Report of the Special Representative of the Secretary-General on the Issue of Human Rights and Transnational Corporations and Other Business Enterprises: Protect, Respect and Remedy: a Framework for Business and Human Rights, delivered to the Human Rights Council, A/HRC/8/5, 7 April 2008.

\section{Ruggie 2009}

J.G. Ruggie, Keynote Presentation at EU Presidency Conference on the 'Protect, Respect and Remedy' Framework, Stockholm, November, 10-11, 2009 (http://esiligies.files.wordpress.com/2009/11/ruggie-stockholmaddress1.pdf).

\section{Ruggie 2010}

Corporate Law Project, overarching trends and observations, July 2010, available at http://www2.ohchr.org/english/bodies/hrcouncil/ docs/17session/A-HRC-17-31-Add2.pdf. 
Ruggie 2011

The Special Representative of the Secretary-General, Report of the Special Representative of the Secretary-General on the issue of human rights and transnational business corporations and other business enterprises, Guiding Principles on Business and Human Rights: Implementing the United Nations "Protect, Respect and Remedy" Framework, A/HRC/17/31, 21 March 2011.

Van der Sangen 2009

G.J.H. van der Sangen, Concernleiding en aansprakelijkheid: het delicate evenwicht tussen unitaire leiding en juridische zelfstandigheid, Tijdschrift voor Ondernemingsbestuur 2009-6, p. 146-153.

Schweisfurth 2011

L. Schweisfurth, The Corporate Response To Allegations Of Human Rights Abuse: An analysis of responses published by the BUSINESS \& HUMAN RIGHTS RESOURCE CENTRE, E.MA Masters In Human Rights And Democratisation 2010-2011.

Schmieman 2004

E. Schmieman, De bevoegdheden van de Advocaat-generaal bij het Gerechtshof Amsterdam in het Enqueterecht (art 2:345 lid 2 en 2:355 lid 1 BW), in: Geschriften vanwege de Vereniging Corporate Litigation 20032004, Deventer: Kluwer 2004.

Schoordijk, 2005

B.J. Schoordijk, "Risk management als hoeksteen van corporate governance " in: S.H.A. Dumoulin ea (red.), Tussen Themis en Mercurius, Bedrijfsjuridische bijdragen aan een Europese beleidsconcurrentie, Lustrumuitgave Nederlands Genootschap van Bedrijfsjuristen, Deventer: Kluwer 2005, p. 309-329.

Sen 2009

Amartya Sen, The Idea of Justice, Penguin (paperback edition, 2010), p. 361-364.

Senden 2005

L. Senden, Soft Law, Self-regulation and co-regulation in European Law: where do they meet. Electronic Journal of Comparative Law, 2005 (to be found at www.ejcl.org). 
SER 2000

Sociaal Economische Raad, De Winst van waarden, Advies over maatschappelijk ondernemen, uitgebracht aan de Staatssecretaris van Economische Zaken (Advies van 15 december 2000, SER 2000/11), Den Haag: SER 2000.

SER 2008a: Sociaal Economische Raad, Duurzame Globalisering: een wereld te winnen, Advies uitgebracht aan de Staatssecretaris van Economische Zaken en de Minister van Sociale Zaken en Werkgelegenheid (advies van 20 juni 2008, SER 2008/06) Den Haag: SER 2008.

SER $2008 b$

Sociaal Economische Raad, Verklaring Internationaal Maatschappelijk Verantwoord Ondernemen (op 19 december 2008 ondertekend door SER en sociale partners) Den Haag: SER 2008.

Sherman and Pitts 2008

John Sherman and Chip Pitts, Human Rights Corporate Accountability Guide: from Law to Norms to Values (Business Leaders Initiative on human Rights, December 2008).

Sjåfjell 2009

B. Sjåfjell Towards a Sustainable European Company Law. A Normative Analysis of the Objectives of EU Law, with the Takeover Directive as a Test Case (Alphen aan den Rijn, Kluwer Law International, 2009).

Sjåfjell 2010

B. Sjåfjell 'Internalizing Externalities in EU Law: Why Neither Corporate Governance nor Corporate Social Responsibility Provides the Answers' The George Washington International Law Review 40 (2010) pp. 977-1024.

Sjåfjell 2011

B. Sjåfjell, Why Law Matters: Corporate Social Irresponsibility and the Futility of Voluntary Climate Change Mitigation (March 2, 2011). European Company Law, Vol. 8, Nos. 2-3, pp. 56-64, 2011; University of Oslo Faculty of Law Research Paper No. 2011-04. 
Slagter 1988

W.J. Slagter, Enkele rechtsvergelijkende beschouwingen over moederdochterverhoudingen, Preadvies Nederlandse Vereniging voor rechtsvergelijking, Deventer: Kluwer 1988.

Slagter 1990

W.J. Slagter's antwoord op Raaijmakers 1990, in TVVS 1990, nr 90/2.

Slagter 2005

Compendium Ondernemingsrecht, 8e druk, Deventer: Kluwer, 2005.

Steins Bisschop 2004

B.T.M. Steins Bisschop, Maatschappelijk ondernemen en het ondernemingsrecht, Den Haag: Boom 2004.

Steins Bisschop 2008

B.T.M. Steins Bisschop, Bescherming tegen niet geïnviteerde overnames en ongewenst aandeelhoudersactivisme (Oratie Maastricht 2008), Zutphen: Paris 2008.

Stiglitz 2002

J. Stiglitz, Globalization and its discontents, W.W. Norton, New York, 2002.

Stiglitz 2006

J, Stiglitz, Making Globalisation Work: The Next Steps to Global Justice, Camberwell: Allen Lane, Penguin Books 2006.

Strik 2009

D.A.M.H.W.Strik, Deelll -Aansprakelijkheid voorfalend risicomanagement, in: Ondernemingsbestuur en risicobeheersing op de drempel van een nieuw decennium: een ondernemingsrechtelijke analyse, Preadvies van de Vereeniging 'Handelsrecht' 2009, Deventer: Kluwer 2009.

Teubner 1985

G. Teubner, 'Corporate fiduciary duties and their beneficiaries', in K.J. Hopt and G. Teubner (eds.), Corporate Governance and Directors' liabilities: Legal, economic and Sociological Analyses on Corporate Social Responsibility, Berlin: Walter de Gruyter, 1985 p. 149. 
Teubner 2009

G. Teubner, Self-Constitutionalizing TNCs? On the Linkage of "Private" and "Public" Corporate Codes of Conduct, in: Gralf-Peter Calliess (Hrsg.) Governing Transnational Corporations - Public and Private Perspectives, Indiana Journal of Global Legal Studies 17, 2010) (http://www.jura.unifrankfurt.de/I_Personal/em_profs/teubner/ dokumente/CSR_conference_bremen.pdf).

Thaler \& Sunstein 2009

R.H. Thaler en C.R. Sunstein Nudge, Improving decisions about health, wealth and happiness London: Penguin 2009.

\section{Timmerman 1988}

L. Timmerman, De concretisering van vage normen in het vennootschapsrecht, in: Van Vennootschappelijk Belang, Opstellen aangeboden aan Prof. Mr J.M.M. Maeijer, Tjeenk Willink Zwolle, 1988, p. 337-347.

\section{Timmerman 2002}

L.Timmerman,'Hebben wij in Nederland nog behoefte aan concernrecht?', in: Concernverhoudingen, Serie vanwege het van der Heijden Instituut, Deventer: Kluwer 2002, p. 13-27.

Timmerman 2009

L. Timmerman, De grondslagen van geldend ondernemingsrecht (Oratie Rotterdam), in Ondernemingsrecht, 2009-1.

Tjong Tjin Tai 2007

T.F.E. Tjong Tjin Tai, Zorgplichten en zorgethiek (diss. UVA 2007), Deventer: Kluwer 2007.

Tricker 2009

Bob Tricker, Corporate Governance, principles, policies and practices, Oxford: Oxford University Press 2009.

Triggs 2006

Gillian D Triggs, International Law, contemporary principles and practices, LexisNexis Butterworths, Australia, 2006. 
Triple Value \& Rinnooy Kan 2008

Triple Value Strategy Consulting \& Rinnooy Kan \& Partners, Geborgd of Verborgen, Maatschappelijk Ondernemen in Corporate Governance, Onderzoeksrapport 2008 www.ez.nl.

Tyler 2006

T.R. Tyler, Why people obey the law, Princeton University Press, Princeton and Oxford, 2006.

UN Draft Norms 2003

Draft Human Rights Principles and Responsibilities for Transnational Corporations and other Business Enterprises, Introduction, UN Doc. E/ CN.4/sub2/2002/XX/Add 1 (2002).

Vandekerckhove 2007

K.Vandekerckhove, 'Piercing the Corporate Veil, A Transnational Approach', Dissertatie Leuven, New York: Kluwer International Law 2007.

Vranken 2006

J.B.M. Vranken, Exploring the Jurist's Frame of Mind, constraints and preoccupations in civil law agumentation, Kluwer, The Netherlands Lluwer Law international - 2006.

De Waard 2008

D. De Waard, Toezicht op maatschappelijk ondernemen (diss. Groningen) Assen: van Gorkum 2008.

Waddell 2011

S. Waddell, Global Action Networks, Creating Our Future Together, Bocconi Universtity Press, 2011.

Walsh/Lowry 2005

M. Walsh \& J. Lowry, 'CSR and Corporate Governance', in Mulllerat 2005, p. 37-6o.

Ward 2003

H. Ward, Legal Issues in Corporate Citizenship, prepared for The Swedish Partnership for Global Responsibility, IIED Publication 〈wWw.iied.org〉. 
Westerman \& Mackor 2008

P.C. Westerman en A. Mackor (red), Vormen van (de?)regulering, Den Haag: Boom 2008 (Westerman \& Mackor 2008).

World Commision on Environment and Development ("Brundtland Commision"): Our Common Future (1987).

Zerk, 2006

J.A. Zerk, Multinationals and Corporate Social Responsibility, Cambridge Studies in International and comparative Law, Cambridge University Press, 2006.

Zumbansen 2009

P. Zumbansen, THE EVOLUTION OF THE CORPORATION: ORGANIZATION, FINANCE, KNOWLEDGE AND CORPORATE SOCIAL RESPONSIBILITY, CLPE Research Paper 06/2009, Vol. 05 No. 01 (2009) Electronic copy available at: http://ssrn.com/abstract $=1346971$.

Zumbansen 2011

P. Zumbansen, The Future of Legal Theory, in Muller e.a., The Law of the Future and the Future of Law, HiiL, FICHL Publication Series No. 11 (2011). 
